\title{
Surveys of Significant Plant Resources in Southeast and South-central Montana on the Billings and Miles City Field Offices of the Bureau of Land Management
}

\author{
Prepared for: \\ Bureau of Land Management \\ Montana State Office and the \\ Billings and Miles City Field Offices
}

By:

Scott Mincemoyer

Montana Natural Heritage Program

Natural Resource Information System

Montana State Library

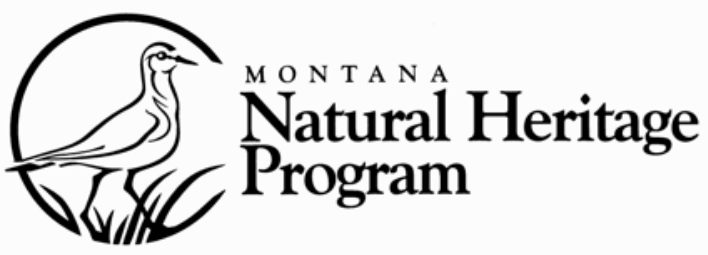





\title{
Surveys of Significant Plant Resources in Southeast and South-central Montana on the Billings and Miles City Field Offices of the Bureau of Land Management
}

\author{
Prepared for:
}

Bureau of Land Management

Montana State Office and the

Billings and Miles City Field Offices

Agreement Number:

ESA010009 - \#26

By:

Scott Mincemoyer
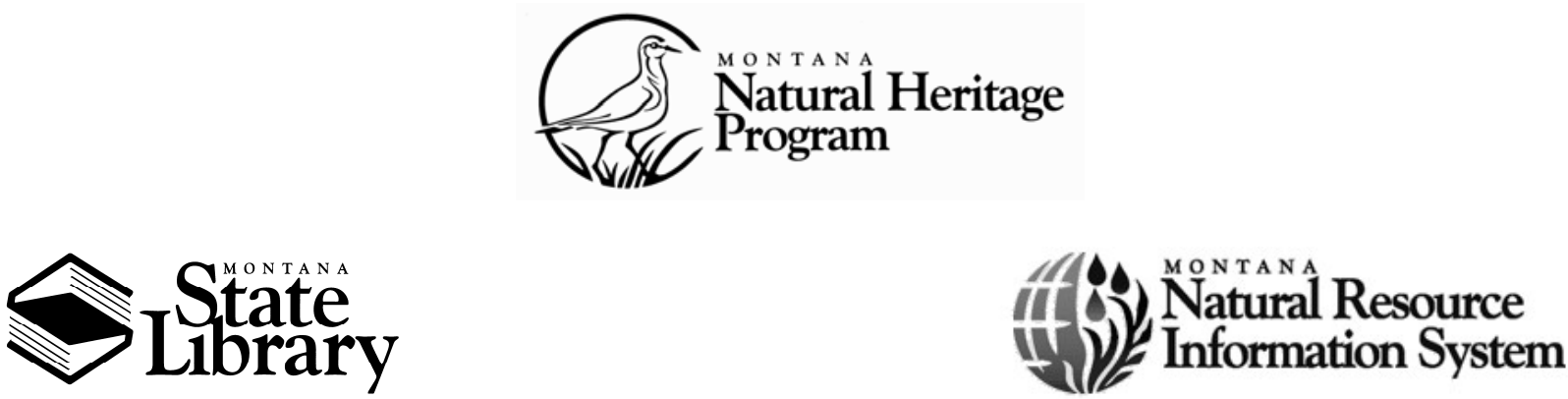

(C) 2006 Montana Natural Heritage Program

P.O. Box 201800 • 1515 East Sixth Avenue • Helena, MT 59620-1800 • 406-444-5354 
This document should be cited as follows:

Mincemoyer, S. 2006. Surveys of Significant Plant Resources in Southeast and South-central Montana on the Billings and Miles City Field Offices of the Bureau of Land Management. Report to the USDI Bureau of Land Management, Billings and Miles City Field Offices. Montana Natural Heritage Program, Helena, MT. 22 pp. + appendices. 


\section{EXECUTIVE SUMMARY}

Lands managed by the Billings and Miles City Field Offices of the Bureau of Land Management (BLM) cover large areas of southcentral and eastern Montana. However, for purposes of this report, the project area is limited to BLM lands in Big Horn, Carbon, Carter, Custer, Fallon, Powder River, Prairie and Rosebud Counties, and excludes the northeast portion of the Miles City Field Office as well as Billings Field Office lands outside of Big Horn and Carbon Counties.

The distribution of BLM lands in this area varies from large tracts of land covering areas of tens of thousands of acres to very small isolated tracts less than a square mile in size. Surface acres managed by the Billings Field Office were listed at 454,859 acres in 2003 and 245,742 acres in the two target counties (Big Horn and Carbon). BLM lands in Carbon County alone account for over 200,000 acres. In the Miles City Field Office, 2.7 million acres are under BLM management, with almost 1.9 million acres of that total in the seven targeted counties, bringing the total potential survey acreage in the project area to approximately 2.1 million acres.

The purpose of this report is to document the results of surveys in 2005 and 2006 for plant Species of Concern (SOC) on lands administered by the two Field Offices and to provide information pertinent to management of these species. However, a great deal of information pertaining to the ecology, distribution, abundance and management of several of these taxa is still lacking and the collection of much of that information is beyond the scope of this provincial project. Information on biology, ecology, rank factors and management as it pertains to individual Species of Concern can be found on the Montana
Natural Heritage Program (MTNHP) website (www.mtnhp.org).

Plant Species of Concern in Montana currently include all S1 and S2 taxa along with G3 (globally vulnerable) taxa. Many of these species are also ranked as "Sensitive" on BLM lands in the state (Bureau of Land Management 2005).

The field surveys conducted during this project help to provide a clearer picture of the abundance and distribution of these species, not only on BLM Field Office lands, but across the project area. Positive survey results, as well as negative survey results (not finding a species in a particular location), provide valuable information that will be useful for conservation planning and management decisions across BLM lands and other ownerships in the state.

Field surveys conducted as part of this study in 2005-2006 documented new locations of Physaria brassicoides, Haplopappus carthamoides var. subsquarrosus and Sphaeromeria capitata. Known occurrences of Cleome lutea and Eriogonum visheri were resurveyed and their mapped locations expanded. Four occurrences of Astragalus grayi and two occurrences of Mentzelia pumila in Carbon County were re-surveyed and their locations and extent better documented. The locations of several other SOC occurrences were revisited, though the surveys failed to relocate the target species.

Additionally, one species that has been reported for the state, Cirsium pulcherrimum was conclusively documented on BLM lands from an area of Powder River County. 


\section{ACKNOWLEDGEMENTS}

Thanks to Dr. David Keil at California Polytechnic State University for verifying the identification of Cirsium pulcherrimum specimens collected during fieldwork conducted as part of this project. Thanks to Cathy Seibert at the Montana State University Herbarium for providing access to the collections there. At the MTNHP, Linda Vance conducted field surveys and provided valuable data and input, Coburn Currier checked the spatial representations of most of the SOC occurrences in the two BLM Field Offices and re-mapped many of these to improve their accuracy and precision, and Kathy Lloyd entered and checked the tabular data for all SOC occurrences on the two Field Offices. As always, thanks to Kathy Lloyd and Coburn Currier for editing and final printing, though any omissions or errors are of my own doing. 


\section{TABLE OF CONTENTS}

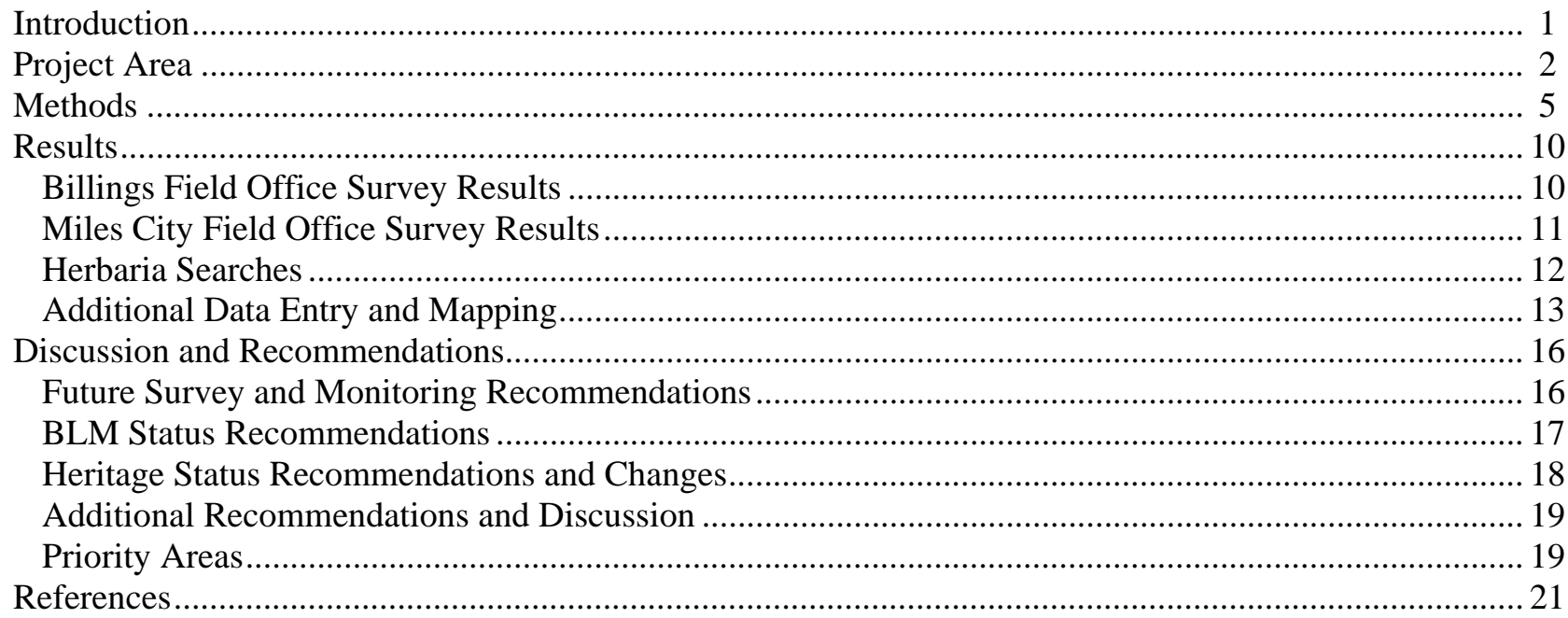

Appendix A. Global/State Rank Definitions

Appendix B. Maps of General Survey Areas and Routes Listed by County

Appendix C. Species Account for Cirsium pulcherrimum

\section{LIST OF FIGURES}

Figure 1. Billings Field Office with general locations of MTNHP Species of Concern.......................... 3

Figure 2. Miles City Field Office with general locations of MTNHP Species of Concern. ..................... 4

\section{LIST OF TABLES}

Table 1. Vascular Plant Species of Concern known from BLM lands in the project area....................... 5

Table 2. Additional Vascular Plant Species of Concern known from ownerships other than BLM........ 8

Table 3. Areas of BLM land surveyed during this project with major findings ..................................... 13 



\section{INTRODUCTION}

Lands administered by the Bureau of Land Management (BLM) cover vast and diverse areas of Montana. As such, BLM lands provide significant habitat for many species of conservation concern within the state. BLM lands in the Billings and Miles City Field Offices are no different and accordingly harbor significant populations of several vascular plant Species of Concern.

Plant Species of Concern (SOC) in Montana currently include all S1 and S2 taxa along with G3 (globally vulnerable) taxa. Many of these species are also ranked as "Sensitive" on BLM lands in the state (Bureau of Land Management 2005). See Appendix A for a full description of global and state rank definitions.

Numerous surveys and reports are available that document vascular plants on BLM-administered lands within the Billings and Miles City Field Offices. These surveys and reports include the following:

Botanical surveys in Carter County (Vanderhorst et al. 1998), surveys for globally significant plants in parts of Big Horn and Rosebud Counties (Barton and Crispin 2003), surveys in Hanging Women Basin in Big Horn County (Carlson and Cooper 2003), surveys for Astragalus barrii and Physaria didymocarpa var. lanata in parts of Big Horn and Rosebud Counties (Taylor and Caners 2002), plant Species of Concern in Powder River County (Heidel et al. 2002), botanical survey of the Tongue River area (Heidel 1997), surveys for Quercus macrocarpa (Heidel 1993) and vascular plant surveys in the Pryor Mountain Desert (Lesica and Achuff 1992a).

Several other pertinent reports on plant Species of Concern in the area are also available, including sensitive plant surveys on the Ashland District of the Custer National Forest (Heidel and Marriott 1996), sensitive plant surveys in the Sioux District, Custer National Forest (Heidel and Dueholm 1995), rare plants of the Bighorn Canyon National
Recreation Area (Heidel and Fertig 2000), conservation status of Eriogonum x lagopus [Eriogonum brevicaule var. canum] (Lesica and Achuff 1992b), conservation status of Haplopappus carthamoides var. subsquarrosus (Lesica 1995a), conservation status of Shoshonea pulvinata (Shelly 1988), conservation status of Lesquerella lesicii (Lesica 1995b), status review of Astragalus barrii (Schassberger 1988) and monitoring Shoshonea pulvinata in the Pryor and Beartooth Mountains (Heidel 2001).

The purpose of this report is to document the results of surveys in 2005 and 2006 for Species of Concern on lands administered by the two Field Offices and to provide information pertinent to management of these species. However, a great deal of information pertaining to the ecology, distribution, abundance and management of several of these taxa is still lacking and the collection of much of that information is beyond the scope of this provincial project. Information on biology, ecology, rank factors and management as it pertains to individual Species of Concern can be found on the MTNHP website (www.mtnhp.org).

The field surveys conducted during this project help to provide a clearer picture of the abundance and distribution of these species, not only on BLM Field Office lands, but across the project area. Positive survey results, as well as negative survey results (not finding a species in a particular location), provide valuable information that will be useful for conservation planning and management decisions across BLM lands and other ownerships in the state. This is the third project completed in recent years that documents plant SOC on BLM land. Previously, BLM lands managed by the Dillon and Butte Field Offices were surveyed in 2002-2003 and 2003-2005 respectively (Lesica 2003, Mincemoyer 2005).

Nomenclature and taxonomy in this report generally follows Vascular Plants of Montana (Dorn 1984) and Vascular Plants of Wyoming Third Edition (Dorn 2001). 


\section{Project Area}

Lands managed by the Billings and Miles City Field Offices of the Bureau of Land Management (BLM) cover large areas of south-central and eastern Montana. However, for purposes of this report, the project area is limited to BLM lands in Big Horn, Carbon, Carter, Custer, Fallon, Powder River, Prairie and Rosebud Counties, and excludes the northeast portion of the Miles City Field Office as well as Billings Field Office lands outside of Big Horn and Carbon Counties. Figures 1 and 2 provide locations of the project area as well as the general location of BLM lands within these areas.

The distribution of BLM lands in this area varies from large tracts of lands covering areas of tens of thousands of acres to very small isolated tracts less than a square mile in size. Surface acres managed by the Billings Field Office were listed at 454,859 acres in 2003 and 245,742 acres in the two target counties (Big Horn and Carbon). BLM lands in Carbon County alone account for over 200,000 acres. In the Miles City Field Office, 2.7 million acres are under BLM management, with almost 1.9 million acres of that total in the seven targeted counties, bringing the total potential survey acreage in the project area to approximately 2.1 million acres.
BLM lands in the project area generally occur in valley bottoms or on lower mountain slopes.

Many areas are dominated by highly dissected or badlands topography with sparse vegetation cover. A continental, semi-arid climate prevails over the project area. Livestock grazing is one of the primary land uses across the region.

Dominant vegetation in the area is sagebrush steppe, wheatgrass-needlegrass grasslands, salt desert scrub, desert scrub and woodlands of juniper, ponderosa pine and limber pine. Sagebrush species that may be locally dominant are Artemisia tridentata ssp. wyomingensis (Wyoming big sagebrush), Artemisia nova (black sagebrush) and Artemisia pedatifida (birdsfoot sage), the latter species being confined to the Bighorn Basin of Carbon County. Other woody species that may be locally dominant or codominant include Chrysothamnus nauseosus (rubber rabbitbrush), and Atriplex confertifolia (shadscale) and A. gardneri (Gardner's saltbush) in saline or alkaline sites. Non-native plant species are common in many parts of the project area with the introduced annual brome grasses, Bromus tectorum (cheatgrass) and B. japonicus (Japanese brome) the most widespread and abundant. 
Figure 1. Billings Field Office with general locations of MTNHP Species of Concern. Only the portion of the Field Office in Carbon County is displayed within the larger map. BLM lands in Big Horn County are shown with the Miles City Field Office in Figure 2.

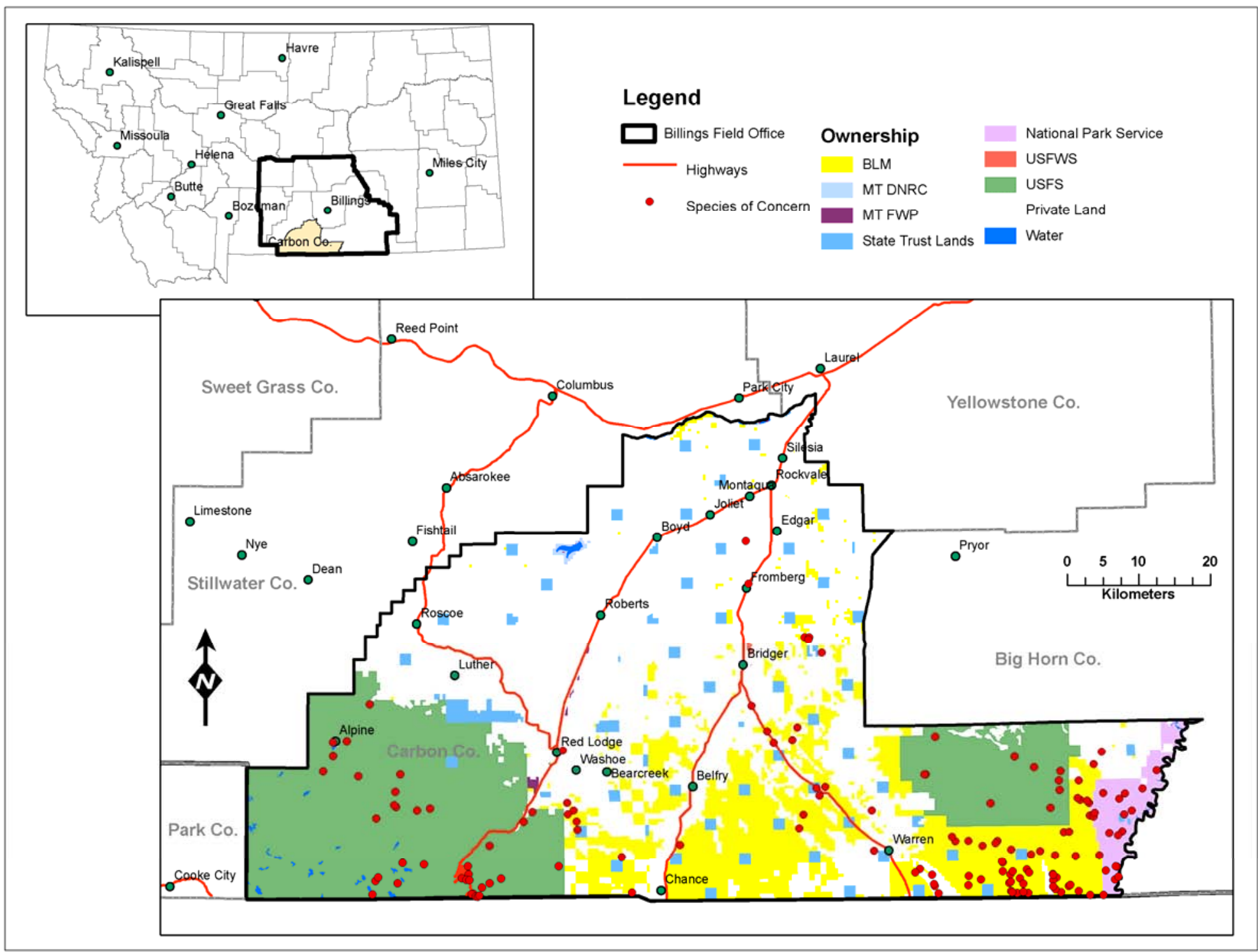


Figure 2. Miles City Field Office with general locations of MTNHP Species of Concern. Only areas within the seven southeastern Montana counties are highlighted within the larger map.

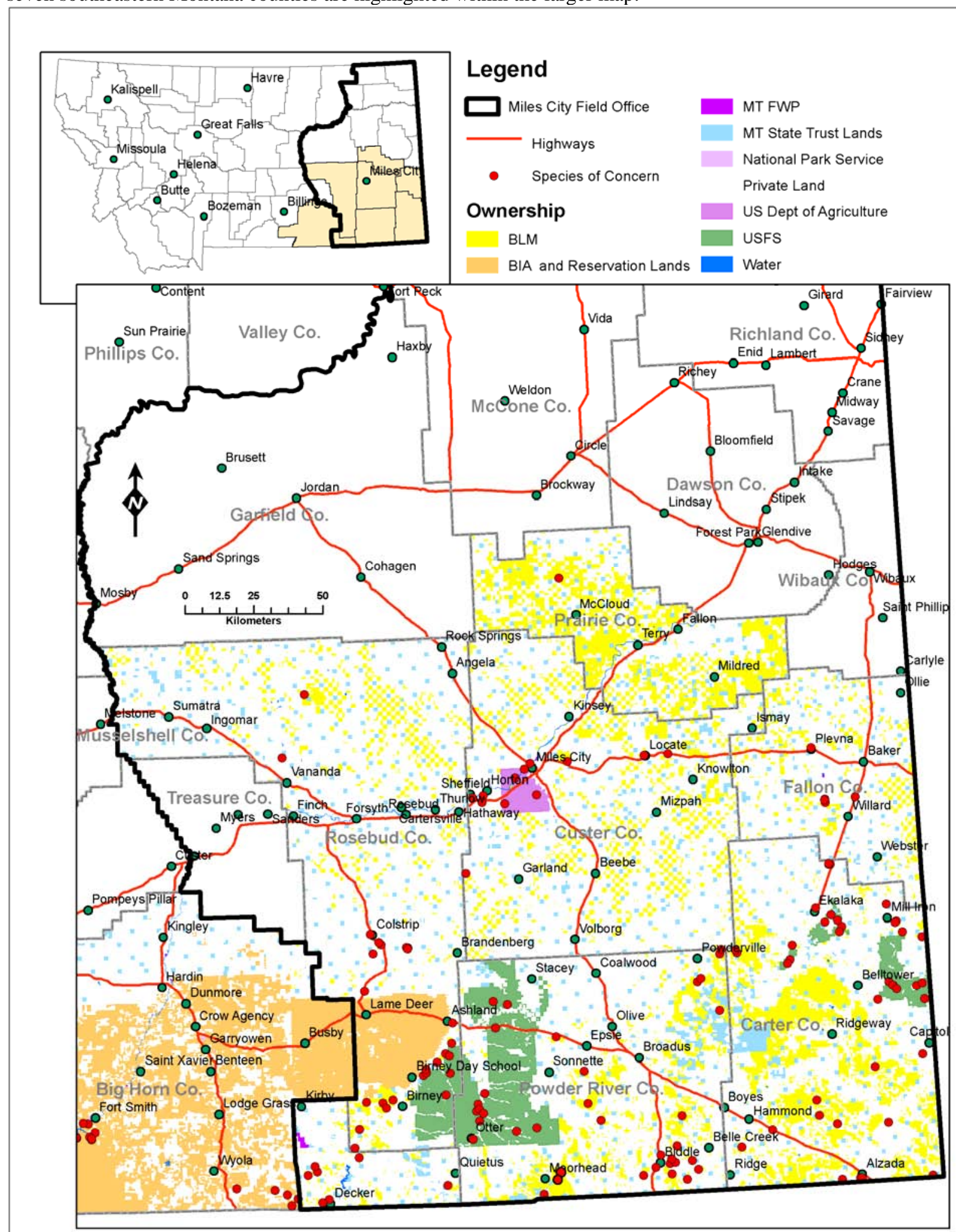




\section{METHODS}

Before the start of the 2005 field season potential sample areas were identified by BLM staff and the MTNHP. Target vascular plant species identified for survey include all BLM Sensitive plants from the area (Table 1) and several additional SOC in the area that had not been located on BLM lands prior to 2005 (Table 2). Field surveys were conducted by Heritage Program Botany and Ecology staff during 2005-2006.

Surveys were concentrated in areas listed in Table 3. In addition to the fieldwork component, visits to the University of Montana Herbarium (MONTU) and Montana State University Herbarium (MONT) were conducted to document existing occurrences for the Field Office and to collect specimen locations for many of the target species. Existing element occurrences in the MTNHP database were also checked for accuracy of locational data and spatial representation. This step was important due in part to a previous upgrade in database software that allows for digitally mapping polygonal features in contrast to the old software which only allowed for tracking occurrences as individual points. All survey data collected during this project will be entered into MTNHP databases.

Conditions in 2005 appeared optimal for the growth and flowering of many species in the project area. Precipitation was abundant in the spring and throughout the growing season. In contrast, 2006 was a dry year and thus not optimal for conducting some of the surveys. Drought conditions during the second year undoubtedly made it more difficult to detect plant populations because growth and flowering were reduced for many species. Field surveys were conducted by Linda Vance in 2005 and by the author in 2005 and 2006.

Locations of all SOC encountered during surveys were documented on a MTNHP Plant Species of Concern Survey Form - 2005 Revision (www.mtnhp.org). Information on abundance, specific location and area of occupancy, associated species and non-native species was recorded. Locations were georeferenced with a GPS receiver.

Table 1. Vascular Plant Species of Concern known from BLM lands within the project area prior to 2006.

\begin{tabular}{|l|c|c|c|l|}
\hline Taxa & $\begin{array}{c}\text { BLM } \\
\text { Status }\end{array}$ & $\begin{array}{c}\text { Global } \\
\text { Rank }\end{array}$ & $\begin{array}{c}\text { State } \\
\text { Rank }\end{array}$ & County Distribution \\
\hline $\begin{array}{c}\text { Arabis demissa } \\
\text { (daggett rock cress) }\end{array}$ & Sensitive & G5 & S1 & Carbon \\
\hline $\begin{array}{c}\text { Asclepias stenophylla } \\
\text { (narrowleaf milkweed) }\end{array}$ & Sensitive & G4G5 & S1 & Carter, Rosebud \\
\hline $\begin{array}{c}\text { Astragalus aretioides } \\
\text { (sweetwater milkvetch) }\end{array}$ & Sensitive & G4 & S1 & Big Horn, Carbon \\
\hline $\begin{array}{c}\text { Astragalus barrii } \\
\text { (Barr's milkvetch) }\end{array}$ & Sensitive & G3 & S3 & $\begin{array}{l}\text { Big Horn, Carter, Powder River, } \\
\text { Rosebud }\end{array}$ \\
\hline $\begin{array}{c}\text { Astragalus geyeri } \\
\text { (Geyer's milkvetch) }\end{array}$ & Sensitive & G4 & S2 & Carbon, Custer, Dawson, Garfield \\
\hline $\begin{array}{c}\text { Astragalus grayi } \\
\text { (Gray's milkvetch) }\end{array}$ & Sensitive & G4? & S1S2 & Carbon \\
\hline $\begin{array}{c}\text { Astragalus oreganus } \\
\text { (Wind River milkvetch) }\end{array}$ & Sensitive & G4? & S1 & Carbon \\
\hline $\begin{array}{c}\text { Astragalus racemosus } \\
\text { (raceme milkvetch) }\end{array}$ & G5 & S2 & Carter, Fallon \\
\hline $\begin{array}{c}\text { Camissonia andina } \\
\text { (obscure evening-primrose) }\end{array}$ & Sensitive & G4 & S1 & Carbon, Missoula, Ravalli \\
\hline $\begin{array}{c}\text { Camissonia parvula } \\
\text { (small camissonia) }\end{array}$ & Sensitive & G5 & S1 & Carbon \\
\hline $\begin{array}{c}\text { Carex crawei } \\
\text { (Crawe's sedge) }\end{array}$ & G5 & S2 & $\begin{array}{l}\text { Cascade, Pondera, Powell, Prairie, } \\
\text { Teton }\end{array}$ \\
\hline
\end{tabular}




\begin{tabular}{|c|c|c|c|c|}
\hline Taxa & $\begin{array}{l}\text { BLM } \\
\text { Status }\end{array}$ & $\begin{array}{l}\text { Global } \\
\text { Rank }\end{array}$ & $\begin{array}{l}\text { State } \\
\text { Rank }\end{array}$ & County Distribution \\
\hline $\begin{array}{l}\text { Chenopodium subglabrum } \\
\text { (smooth goosefoot) }\end{array}$ & & G3G4 & S1 & $\begin{array}{l}\text { Carter, Cascade, Custer, Powder River, } \\
\text { Sheridan }\end{array}$ \\
\hline $\begin{array}{l}\text { Cleome lutea } \\
\text { (yellow bee plant) }\end{array}$ & Sensitive & G5 & S1 & Big Horn, Carbon \\
\hline $\begin{array}{l}\text { Cryptantha scoparia } \\
\text { (miner's candle) }\end{array}$ & Sensitive & G4? & S1 & Carbon \\
\hline $\begin{array}{l}\text { Cyperus schweinitzii } \\
\text { (Schweinitz' flatsedge) }\end{array}$ & Sensitive & G5 & S2 & $\begin{array}{l}\text { Carter, Cascade, Custer, Powder River, } \\
\text { Sheridan }\end{array}$ \\
\hline $\begin{array}{l}\text { Dalea enneandra } \\
\text { (nine-anther dalea) }\end{array}$ & & G5 & S1 & Big Horn, Custer, Fallon, Richland \\
\hline $\begin{array}{l}\text { Dalea villosa } \\
\text { (silky prairie clover) }\end{array}$ & & G5 & S1 & Carter, Richland, Sheridan \\
\hline $\begin{array}{l}\text { Erigeron allocotus } \\
\text { (Big Horn fleabane) }\end{array}$ & & G3 & S3 & Big Horn, Carbon \\
\hline $\begin{array}{l}\text { Eriogonum brevicaule var. } \\
\text { canum (rabbit buckwheat) }\end{array}$ & & G3 & S3 & Big Horn, Carbon \\
\hline $\begin{array}{l}\text { Eriogonum salsuginosum } \\
\text { (Smooth Buckwheat) }\end{array}$ & Sensitive & G4? & S1 & Carbon \\
\hline $\begin{array}{l}\text { Eriogonum visheri } \\
\text { (Visher's buckwheat) }\end{array}$ & Sensitive & G3 & S1 & Carter \\
\hline $\begin{array}{l}\text { Grayia spinosa } \\
\text { (spiny hopsage) }\end{array}$ & Sensitive & G5 & S2 & Beaverhead, Big Horn, Carbon, Park \\
\hline $\begin{array}{l}\text { Haplopappus carthamoides } \\
\text { var. subsquarrosus } \\
\text { (Beartooth goldenweed) }\end{array}$ & Sensitive & G4G5T2T3 & S1S2 & Carbon \\
\hline $\begin{array}{l}\text { Hutchinsia procumbens } \\
\text { (hutchinsia) }\end{array}$ & Sensitive & G5 & S1 & Beaverhead, Carbon, Flathead, Powell \\
\hline $\begin{array}{l}\text { Leptodactylon caespitosum } \\
\text { (leptodactylon) }\end{array}$ & Sensitive & G4 & S2 & Carbon \\
\hline $\begin{array}{l}\text { Lesquerella lesicii } \\
\text { (Lesica’s bladderpod) }\end{array}$ & Sensitive & G1 & S1 & Carbon \\
\hline $\begin{array}{l}\text { Lomatium nuttallii } \\
\text { (Nuttall desert-parsley) }\end{array}$ & Sensitive & G3 & S1 & Big Horn, Rosebud \\
\hline $\begin{array}{l}\text { Malacothrix torreyi } \\
\text { (desert dandelion) }\end{array}$ & Sensitive & G4 & S1 & Carbon \\
\hline $\begin{array}{l}\text { Mentzelia montana } \\
\text { (white-bract stickleaf) }\end{array}$ & Sensitive & G4 & S1 & Beaverhead, Custer \\
\hline $\begin{array}{l}\text { Mentzelia nuda } \\
\text { (bractless mentzelia) }\end{array}$ & Sensitive & G5 & S1 & $\begin{array}{l}\text { Custer, Dawson, Powder River, } \\
\text { Roosevelt, Rosebud, Valley }\end{array}$ \\
\hline $\begin{array}{l}\text { Mentzelia pumila } \\
\text { (dwarf mentzelia) }\end{array}$ & Sensitive & G4 & S2 & Carbon \\
\hline $\begin{array}{l}\text { Nama densum } \\
\text { (nama) }\end{array}$ & Sensitive & G5 & S1 & Carbon \\
\hline $\begin{array}{l}\text { Nuttallanthus texanus } \\
\text { (blue toadflax) }\end{array}$ & & G4G5 & S1 & Carter, Dawson \\
\hline $\begin{array}{l}\text { Penstemon angustifolius } \\
\text { (narrowleaf penstemon) }\end{array}$ & Sensitive & G5 & S1S2 & Carter, Dawson, Fallon, Missoula \\
\hline $\begin{array}{l}\text { Penstemon caryi } \\
\text { (Cary's beardtongue) }\end{array}$ & & G3 & S3 & Carbon \\
\hline $\begin{array}{r}\text { Phlox andicola } \\
\text { (plains phlox) }\end{array}$ & Sensitive & G4 & S2 & $\begin{array}{l}\text { Carter, Dawson, Powder River, } \\
\text { Rosebud, Sheridan }\end{array}$ \\
\hline $\begin{array}{c}\text { Physaria brassicoides } \\
\text { (double bladderpod) }\end{array}$ & Sensitive & G5 & S2 & $\begin{array}{l}\text { Carter, Custer, Petroleum, Powder } \\
\text { River }\end{array}$ \\
\hline
\end{tabular}




\begin{tabular}{|l|c|c|c|l|}
\hline Taxa & $\begin{array}{c}\text { BLM } \\
\text { Status }\end{array}$ & $\begin{array}{c}\text { Global } \\
\text { Rank }\end{array}$ & $\begin{array}{c}\text { State } \\
\text { Rank }\end{array}$ & County Distribution \\
\hline $\begin{array}{l}\text { Physaria didymocarpa var. } \\
\text { lanata (woolly twinpod) }\end{array}$ & Sensitive & G5T2 & S1 & Big Horn, Rosebud \\
\hline $\begin{array}{c}\text { Plagiobothrys leptocladus } \\
\text { (slender popcorn flower) }\end{array}$ & Sensitive & G4 & S1 & Beaverhead, Custer, Glacier, Phillips \\
\hline $\begin{array}{l}\text { Poa curta } \\
\text { (short-leaved bluegrass) }\end{array}$ & Sensitive & G4 & S1 & Carbon \\
\hline $\begin{array}{l}\text { Psoralea hypogaea } \\
\text { (little indian breadroot) }\end{array}$ & Sensitive & G5 & S1 & Carter \\
\hline $\begin{array}{l}\text { Quercus macrocarpa } \\
\text { (bur oak) }\end{array}$ & Sensitive & G3 & S1 & $\begin{array}{l}\text { Big Horn, Cascade, Custer, McCone, } \\
\text { Rosebud, Treasure, Yellowstone }\end{array}$ \\
\hline $\begin{array}{c}\text { Rorippa calycina } \\
\text { (persistent sepal yellowcress) }\end{array}$ & Sensitive & G2G3 & S1 & Carbon \\
\hline $\begin{array}{c}\text { Shoshonea pulvinata } \\
\text { (shoshonea) }\end{array}$ & G3 & S3 & Beaverhead, Carbon, Petroleum, Powder \\
\hline $\begin{array}{c}\text { Sphaeromeria capitata } \\
\text { (rock-tansey) }\end{array}$ & G3 & S3 & $\begin{array}{l}\text { Beaverhead, Broadwater, Carbon, } \\
\text { Madison, Silver Bow }\end{array}$ \\
\hline $\begin{array}{c}\text { Townsendia spathulata } \\
\text { (sword townsendia) }\end{array}$ & & &
\end{tabular}


Table 2. Additional vascular plant Species of Concern, excluding alpine taxa, known from ownerships other than BLM within the project area prior to 2006. Those thought most likely to be documented from BLM lands are highlighted.

\begin{tabular}{|c|c|c|c|c|}
\hline Taxa & $\begin{array}{l}\text { BLM } \\
\text { Status }\end{array}$ & $\begin{array}{c}\text { Global } \\
\text { Rank }\end{array}$ & $\begin{array}{l}\text { State } \\
\text { Rank }\end{array}$ & Habitat \\
\hline $\begin{array}{l}\text { Adoxa moschatellina } \\
\text { (musk-root) }\end{array}$ & Sensitive & G5 & $\mathrm{S} 2$ & Vernally moist, rock slopes \\
\hline $\begin{array}{l}\text { Amorpha canescens } \\
\text { (lead plant) }\end{array}$ & Sensitive & G5 & $\mathrm{SH}$ & Dry prairies \\
\hline $\begin{array}{r}\text { Asclepias incarnata } \\
\text { (swamp milkweed) }\end{array}$ & & G5 & S1 & Wet meadows, thickets \\
\hline $\begin{array}{l}\text { Asclepias ovalifolia } \\
\text { (oval-leaf milkweed) }\end{array}$ & & G5? & S1 & Open, pine woodlands, prairies \\
\hline $\begin{array}{l}\text { Aster ptarmicoides } \\
\text { (prairie aster) }\end{array}$ & & G5 & S1 & Open, dry grasslands \\
\hline $\begin{array}{l}\text { Carex gravida } \\
\text { (pregnant sedge) }\end{array}$ & & G5 & S1S2 & Wooded draws \\
\hline $\begin{array}{l}\text { Carex stenoptila } \\
\text { (small-winged sedge) }\end{array}$ & & G2 & S1S2 & $\begin{array}{l}\text { Grasslands and open forests in the montane } \\
\text { and subalpine zones, and moist soil along } \\
\text { streams in the valleys }\end{array}$ \\
\hline $\begin{array}{l}\text { Ceanothus herbaceus } \\
\text { (New Jersey tea) }\end{array}$ & & G5 & $\mathrm{SH}$ & Pine woodlands \\
\hline $\begin{array}{l}\text { Centaurium exaltatum } \\
\text { (western centaury) }\end{array}$ & & G5 & $\mathrm{SH}$ & Moist soil around ponds and streams \\
\hline $\begin{array}{l}\text { Dichanthelium oligosanthes } \\
\text { var. scribnerianum } \\
\text { (Scribner's panic grass) }\end{array}$ & Sensitive & G5T5 & S1 & Wooded draws \\
\hline $\begin{array}{l}\text { Eleocharis rostellata } \\
\text { (beaked spikerush) }\end{array}$ & Sensitive & G5 & S2 & Wet, often alkaline soils \\
\hline $\begin{array}{l}\text { Epipactis gigantea } \\
\text { (giant helleborine) }\end{array}$ & & G3G4 & $\mathrm{S} 2$ & Seeps and springs (thermal) \\
\hline $\begin{array}{l}\text { Erigeron formosissimus } \\
\text { (beautiful fleabane) }\end{array}$ & & G5 & S1 & $\begin{array}{l}\text { Meadows and forest openings in the montane } \\
\text { and subalpine zones }\end{array}$ \\
\hline $\begin{array}{l}\text { Eupatorium maculatum } \\
\text { Spotted joepye-weed) }\end{array}$ & & G5 & S1S2 & $\begin{array}{l}\text { Moist meadows, springs, stream margins and } \\
\text { swamp thickets in the valleys and on the } \\
\text { plains }\end{array}$ \\
\hline $\begin{array}{l}\text { Gentianopsis simplex } \\
\text { (hiker's gentian) }\end{array}$ & & G5 & S1 & $\begin{array}{l}\text { Fens, meadows, and seeps, usually in areas of } \\
\text { crystalline parent material in the montane and } \\
\text { subalpine zones }\end{array}$ \\
\hline $\begin{array}{l}\text { Hemicarpha drummondii } \\
\text { (Drummond's hemicarpha) }\end{array}$ & & G4G5 & $\mathrm{SH}$ & $\begin{array}{l}\text { Moist, sandy soil along rivers and streams in } \\
\text { the valleys }\end{array}$ \\
\hline $\begin{array}{l}\text { Maianthemum canadense } \\
\text { (wild lily-of-the-valley) }\end{array}$ & & G5 & $\mathrm{SH}$ & $\begin{array}{l}\text { Moist, humic soil in riparian forest on the } \\
\text { plains }\end{array}$ \\
\hline $\begin{array}{l}\text { Penstemon grandiflorus } \\
\text { (large-flowered penstemon) }\end{array}$ & & G5? & S1 & Sandy soil of valleys and plains \\
\hline $\begin{array}{l}\text { Potentilla plattensis } \\
\text { (Platte cinquefoil) }\end{array}$ & Sensitive & G4 & S1 & $\begin{array}{l}\text { Grasslands and sagebrush steppe in the valley } \\
\text { and montane zones }\end{array}$ \\
\hline $\begin{array}{l}\text { Prunus pumila } \\
\text { (sand cherry) }\end{array}$ & & G5 & S1 & Sandy or rocky soils in plains grasslands \\
\hline $\begin{array}{l}\text { Ranunculus jovis } \\
\text { (Jove's buttercup) }\end{array}$ & & & & $\begin{array}{l}\text { Sagebrush grasslands to open forest slopes in } \\
\text { the montane and subalpine zones }\end{array}$ \\
\hline $\begin{array}{l}\text { Senecio eremophilus } \\
\text { (desert groundsel) }\end{array}$ & & G5 & S1S2 & $\begin{array}{l}\text { Moist streambanks and riparian forests in the } \\
\text { valley and montane zones }\end{array}$ \\
\hline $\begin{array}{l}\text { Sporobolus asper } \\
\text { (longleaf dropseed) }\end{array}$ & & G5 & $\mathrm{SH}$ & Open forests and grasslands on the plains \\
\hline
\end{tabular}




\begin{tabular}{|l|c|c|c|l|}
\hline Taxa & $\begin{array}{c}\text { BLM } \\
\text { Status }\end{array}$ & $\begin{array}{c}\text { Global } \\
\text { Rank }\end{array}$ & $\begin{array}{c}\text { State } \\
\text { Rank }\end{array}$ & Habitat \\
\hline $\begin{array}{c}\text { Stipa lettermanii } \\
\text { (Letterman's needlegrass) }\end{array}$ & & G5 & S1 & $\begin{array}{l}\text { Limestone talus and dry fescue grassland in } \\
\text { the valley and foothill zones }\end{array}$ \\
\hline $\begin{array}{c}\text { Sullivantia hapemanii } \\
\text { (Wyoming sullivantia) }\end{array}$ & Sensitive & G3 & S2 & $\begin{array}{l}\text { Calcareous rock walls and boulders at springs, } \\
\text { waterfalls and streambanks }\end{array}$ \\
\hline $\begin{array}{c}\text { Viburnum lentago } \\
\text { (nannyberry) }\end{array}$ & & G5 & S1 & Openings in riparian forests on the plains \\
\hline
\end{tabular}




\section{RESUlts}

Field surveys conducted as part of this study in 2005-2006 documented new locations of Physaria brassicoides, Haplopappus carthamoides var. subsquarrosus and Sphaeromeria capitata. Known occurrences of Cleome lutea and Eriogonum visheri were re-surveyed and their mapped locations expanded. Four occurrences of Astragalus grayi and two occurrences of Mentzelia pumila in Carbon County were re-surveyed and their locations and extent better documented. The locations of several other SOC occurrences were revisited, though the surveys failed to relocate the target species. Maps showing general survey areas and routes are depicted in Appendix B.

Additionally, one species that had previously been reported for the state, Cirsium pulcherrimum (Wyoming thistle) was conclusively documented on BLM lands from an area of Powder River County. In the same area, a collection of another plant may yield another rare plant species, though the collection awaits "final" identification from an expert in that group. See Table 3 for a summary of survey results.

At the end of 2006, over 120 separate locations of two dozen SOC were known from Billings Field Office. Several species are known almost exclusively in Montana from these lands, including Astragalus oreganus, Camissonia parvula, Cleome lutea, Cryptantha scoparia, Malacothrix torreyi, Mentzelia pumila, Nama densum and Poa curta. Numbers for the Miles City Field Office are similar, with 123 separate locations of 21 SOC. Approximately half of these locations are for one species, Astragalus barrii. Other SOC that rely heavily on BLM land in this area are Asclepias stenophylla, Astragalus racemosus, Cyperus schweinitzii, Dalea enneandra, Eriogonum visheri, Lomatium nuttallii, Mentzelia nuda, Nuttallanthus texanus, Penstemon angustifolius, Physaria didymocarpa var. lanata and Quercus macrocarpa.

\section{Billings Field Office Survey Results}

Astragalus grayi EO \#3 southeast of Bridger along Highway 310 was resurveyed and found to be entirely, or almost entirely, on private land.
Previous surveys were too vague and imprecise to determine the exact boundaries. EO \#7, further south of the previous occurrence, was also determined to be almost entirely on state and private lands with perhaps a few plants occurring on BLM lands. This relatively large population was previously mapped as two separate, disjunct occurrences (EO \#'s 7 \& 8).

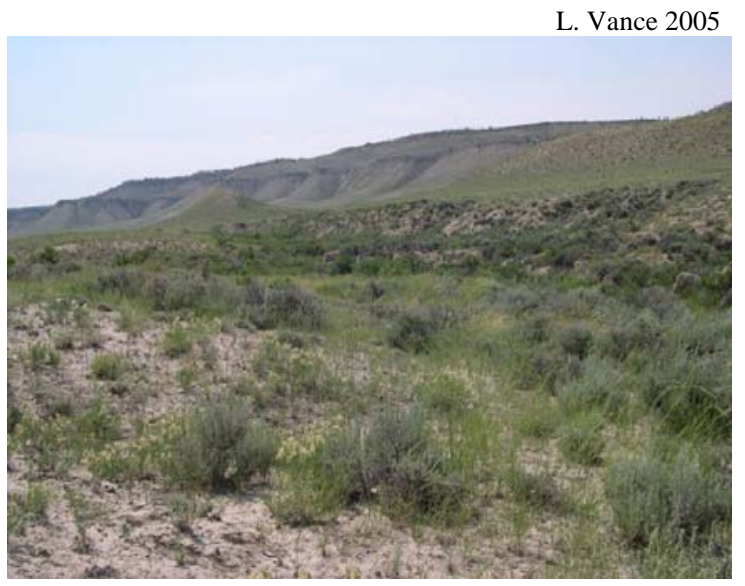

Astragalus grayi habitat south of Bridger

A survey of BLM land for Camissonia andina EO \#7 (Jack Creek) southeast of Bridger failed to relocate the species. This population of the diminutive, annual species was first observed in 1991 and a follow-up survey in 1993 was also unable to relocate the species.

Surveys for Cleome lutea in the Cottonwood Creek, Hunters Creek and Weatherman Draw area greatly expanded the known extent and number of individuals documented in the drainages. Surveys previous to 2005 had documented two separate locations for the species. 2005 surveys observed plants extending across several miles in these drainages. The area is now mapped as EO\#4. Limited observations in 2006 in some of the same areas of the Cottonwood Creek drainage failed to observe any plants (either last year's dead stalks or current season's growth) of C. lutea. This is probably due to unfavorable growing conditions for the species in 2006 in contrast to the favorable conditions of 2005. An additional location of $C$. lutea was located further south along Cottonwood Creek on private land. 


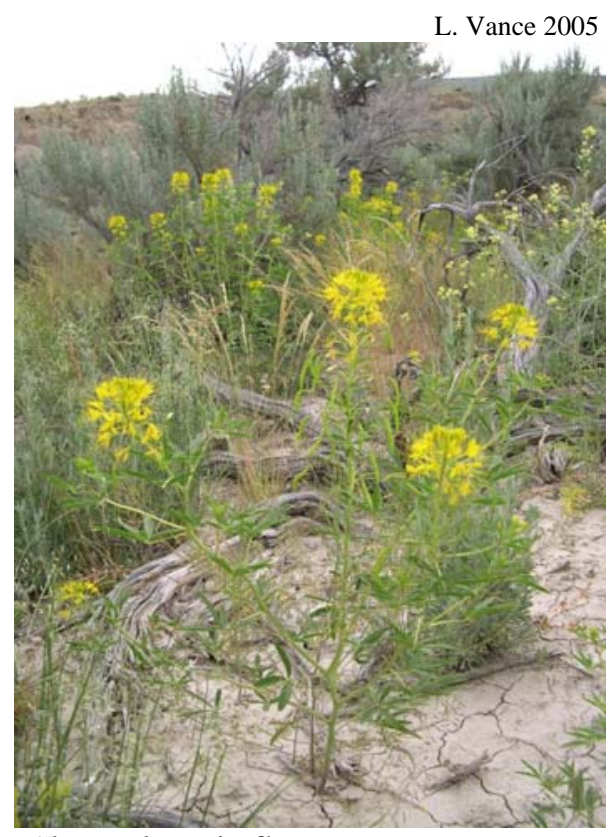

Cleome lutea in flower

One new, small occurrence of Haplopappus carthamoides var. subsquarrosus (EO \#9) was located on BLM lands in the vicinity of other known occurrences on the east slope of the Beartooth Mountains. Another previously known occurrence (EO\# 8) on state trust lands, bordering BLM land, was visited but no $H$. carthamoides var. subsquarrosus was observed on the BLM land. Two other small occurrences (EO \#'s 1 \& 7) on BLM lands in the area were not visited during this trip as the land was falsely marked as private land with "No Trespassing signs." During 2006, two additional occurrences (EO \#'s 5 \& 6) of the plant on National Forest land south of Red Lodge were visited.

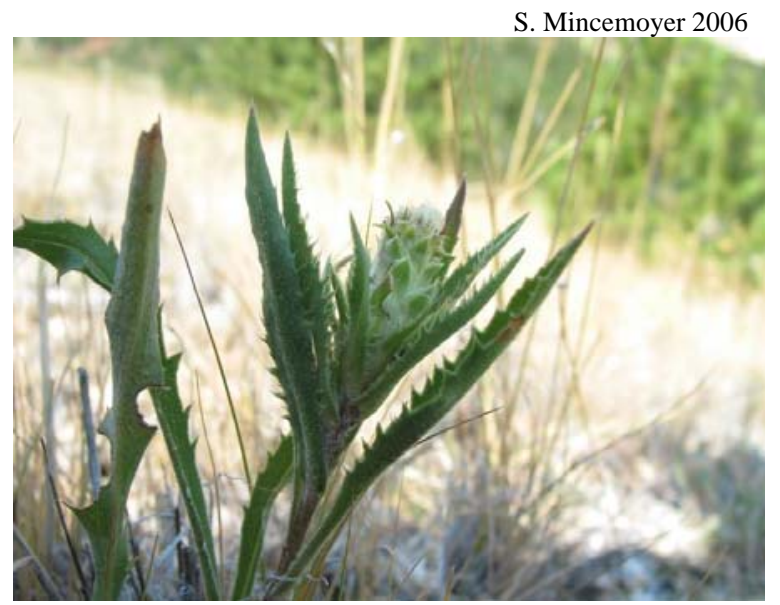

Haplopappus carthamoides var. subsquarrosus
In total, three occurrences of $H$. carthamoides var. subsquarrosus were visited in 2006 that had been previously surveyed in 1995; all showed marked reductions in population numbers. Recent drought conditions in the area are presumed to be the cause of these observed declines.

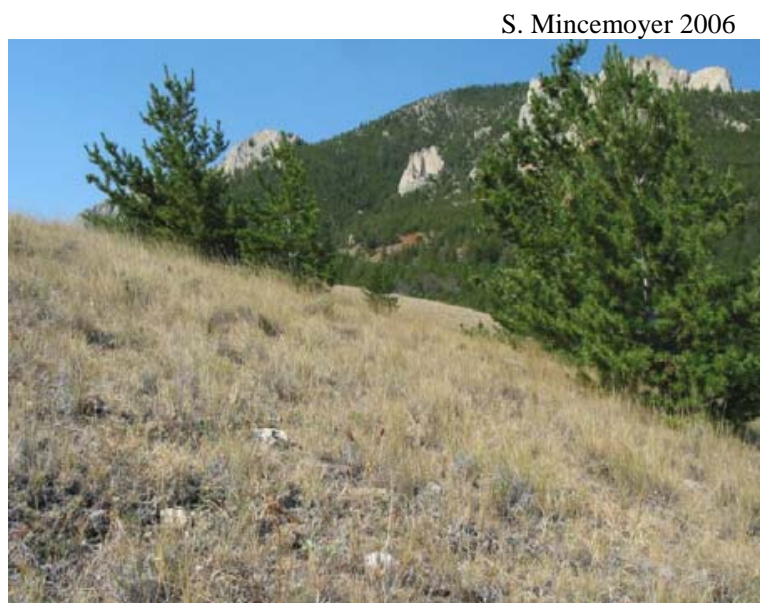

Haplopappus carthamoides var. subsquarrosus habitat on the east slope of the Beartooth Mountains

Two Mentzelia pumila occurrences were revisited. EO\# 5 (Hollenbeck Draw) south of Belfry is entirely on BLM land and its size was determined to be relatively unchanged from a 1991 survey. EO \#1 (South Fork Bridger Creek) is on mixed ownership of private and BLM lands. The population was first observed in 1986 with over 100 individuals. Less than 10 individuals were observed in 2005.

Eriogonum brevicaule var. canum was also observed in the Pryor Mountain Desert/Bighorn Basin, though specific information pertaining to the occurrence was not recorded as the species will no longer be considered a SOC. See comments on this taxon in the Discussion and Recommendation section.

\section{Miles City Field Office Survey Results}

Cirsium pulcherrimum has been previously reported for Montana in Dawson and Treasure Counties (Great Plains Flora Association 1986) though the existence and location of specimen vouchers to document these reports are uncertain. A collection at MONTU (University of Montana Herbarium) from the Pryor Mountains is labeled as 
this species, though its identification is uncertain. In 2006, collections of a thistle were made in and adjacent to the Buffalo Creek Wilderness Study Area (WSA) near Moorhead and it was tentatively identified as C. pulcherrimum using the Flora of the Great Plains (GPFA 1986) and the Flora of North America (Keil 2006). However, no material in Montana herbaria was available that appeared morphologically similar, including the MONTU specimen that is labeled as C. pulcherrimum. Two of the specimens were sent to Dr. David Keil at California Polytechnic State University, author of the FNA treatment on Cirsium, and the identifications were verified as $C$. pulcherrimum.

Within the Buffalo Creek WSA, scattered individuals were located in two general areas (Appendix C). The species appears to be rare in the area and was not observed in other areas of apparently suitable habitat. Previous to this project, the species was ranked SU in Montana; as a result of these new findings the species' rank will change to S1 and it will be added to the Montana SOC list.

The identification of one plant collection from a ridgetop on the border of the Buffalo Creek WSA remains uncertain. The specimen appears to be a Boisduvalia sp. (Onagraceae), though it does not resemble the single species known from eastern Montana, Boisduvalia glabella (smooth spikeprimrose). It more closely resembles $B$. stricta (narrow-leaved boisduvalia) which is not known from Montana, or B. densiflora (dense spikeprimrose) which is known from Montana from one historical collection in the western part of the state. The genus is now more typically treated in an expanded concept of Epilobium. The collection will be sent for identification to an expert in the Onagraceae.

The sole Montana population of Eriogonum visheri growing on BLM lands east of Powderville in the Hell Creek Formation appears to be healthy and in fact may be expanding in size and extent. The entire area previously documented as occupied by the plant was not surveyed in 2005, though other areas not previously noted as occupied now contain E. visheri.
Two new locations of Physaria brassicoides on BLM lands east of Powderville in the Hell Creek Formation were also discovered. These locations have currently been combined into EO \#4. A couple hundred plants were observed in these new areas. One additional location of $P$. brassicoides was discovered in 2005 southeast of Miles City, though the occurrence is on private land (or possibly state land) immediately adjacent to a block of BLM land.

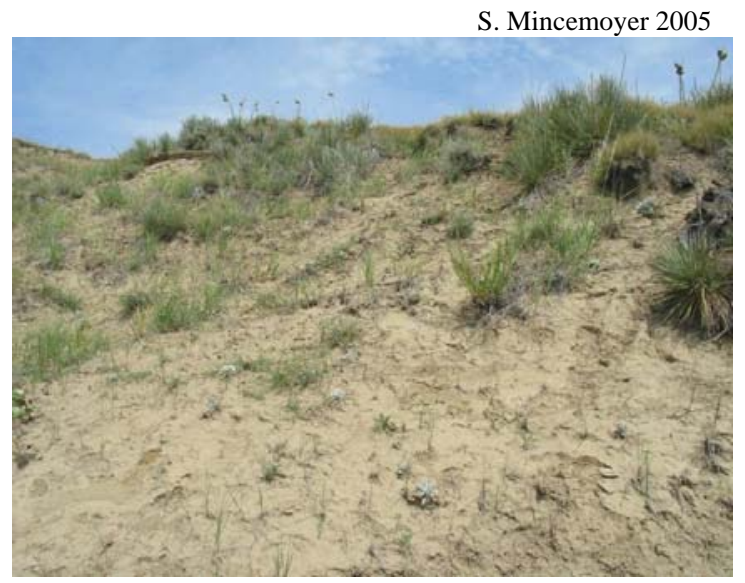

Physaria brassicoides habitat east of Powderville

BLM lands in the Tidwell Draw area were targeted for survey, but poor road conditions due to recent rains prevented travel to the site during a visit to the area.

\section{Herbaria Searches}

Specimen label data for almost all target species listed in Table 1 and for some of those listed in Table 2 were gathered from the University of Montana (MONTU) and the Montana State University (MONT) herbaria in the fall of 2006. Collection of this information resulted in several "new" occurrences, though only one of the new locations was on BLM lands in the project area. The one new location on BLM lands was from a recent collection of Astragalus geyeri in the Pryor Mountain Desert in the vicinity of other known locations.

Specimen label data for only one species, Sullivantia hapemanii, was retrieved from the Rocky Mountain Herbarium (RM) in Wyoming. This resulted in the mapping of one new location in the Bighorn Canyon NRA. 


\section{Additional Data Entry and Mapping}

Data for three globally rare species, for which MTNHP had not been recently tracking occurrence information, have been re-entered into MTNHP databases. BLM lands on the Billings Field Office contain significant occurrences of all three species. The three species are Erigeron allocotus, Penstemon caryi and Townsendia spathulata. At this time, all occurrences of the latter two species have been entered. However, occurrences for Erigeron allocotus reported for the Bighorn Canyon NRA (Heidel and Fertig 2000) have not been entered and it is unclear if the detailed documentation that would allow mapping of these occurrences exists. Also, 19 occurrence records for Psoralea hypogaea, a state rare taxon, have been re-entered into MTNHP databases. This species was previously dropped from tracking by MTNHP, though supporting documentation describing the rationale for this change is incomplete and vague.

In addition to the mapping and entry of new species data, all occurrences on the two BLM Field Offices were reviewed for spatial and tabular data accuracy. Review of the spatial representations for these records resulted in a refinement of the mapped boundaries in many cases and in several additional instances added subpopulations that were documented by surveyors but were not represented in MTNHP spatial data. During this process several hundred mapped features were checked for accuracy and completeness as well as the corresponding tabular data.
As part of the review of all mapped SOC occurrences on the two Field Offices, Astragalus barrii occurrences were reviewed and a change in the protocol for mapping/tracking this species was instituted to help simplify data management and tracking. Though the species is considered globally rare, it is sometimes locally common, with numerous mapped subpopulations or clusters scattered over many square miles and across multiple ownerships. This is often the case when habitat is locally abundant for a particular species but uncommon across the larger landscape. To simplify the tracking of occurrence data and the dissemination of the information, all observed areas of this species provided by surveyors are now mapped as separate locations (i.e. separate Element Occurrences). This methodology is commonly used for tracking SOC animal species in Montana to prevent the creation of very large, unwieldy tracking units. The alternative of tracking data at the population or metapopulation level, which may consist of dozens or even hundreds of individually mapped subpopulations or clusters, is cumbersome and problematic. As a result of this change in methodology, the number of mapped occurrences reported by MTNHP is currently 167 as compared to less than 50 occurrences previously. Other plant SOC are also likely to undergo a shift in tracking methodology. However, further details and discussion of the changes in tracking methodology are not presented here as it is not the purpose of this report.

Table 3. Areas of BLM land surveyed during this project with major findings. Township, Range, Sections are provided to delineate general survey areas. The list is not intended to be a comprehensive inventory of all BLM areas visited nor is it intended to imply that surveys in any of the geographic areas listed below provide comprehensive survey coverage of the area.

\begin{tabular}{|l|c|c|c|c|}
\hline County & Survey Sites & Survey Date & $\begin{array}{c}\text { BLM Sections } \\
\text { Surveyed }\end{array}$ & Results \\
\hline Big Horn & Feeback Draw & July 23, 2005 & $\begin{array}{c}\text { T8S, R43E, sec 9, } \\
10\end{array}$ & No new occurrences \\
\hline Carbon & $\begin{array}{c}\text { Bear Canyon \& se } \\
\text { Pryor Mountains }\end{array}$ & June 6 \& 7, 2006 & $\begin{array}{c}\text { T9S, R26E, sec 3, 4, } \\
9,10\end{array}$ & $\begin{array}{c}\text { Malacothrix torreyi, } \\
\text { and Nama densum not } \\
\text { relocated. 1 new } \\
\text { location of } \\
\text { Sphaeromeria capitata }\end{array}$ \\
\cline { 2 - 5 } & $\begin{array}{c}\text { Inferno Canyon (e } \\
\text { Pryor Mountains) }\end{array}$ & June 5 \& 6, 2006 & $\begin{array}{c}\text { T8S, R25E, sec 15 } \\
\& 16\end{array}$ & No new occurrences \\
\hline
\end{tabular}




\begin{tabular}{|c|c|c|c|c|}
\hline County & Survey Sites & Survey Date & $\begin{array}{l}\text { BLM Sections } \\
\text { Surveyed }\end{array}$ & Results \\
\hline & $\begin{array}{l}\text { HWY } 310 \text { south of } \\
\text { Bridger }\end{array}$ & $\begin{array}{l}\text { June 20-28, } 2005 \\
\text { and June 5, } 2006\end{array}$ & $\begin{array}{l}\text { Scattered sections } \\
\text { adjacent to and near } \\
\text { highway }\end{array}$ & $\begin{array}{l}\text { Revisited } 4 \text { Astragalus } \\
\text { grayi occurrences }\end{array}$ \\
\hline & $\begin{array}{l}\text { Cottonwood Creek- } \\
\text { Hunter's Creek- } \\
\text { Weatherman Draw }\end{array}$ & June 20-28, 2005 & $\begin{array}{l}\text { T8S, R24E, sec 29, } \\
\text { 31, } 32 \\
\text { T9S, R24E, sec 4, 5, } \\
6\end{array}$ & $\begin{array}{l}\text { Surveyed extensive } \\
\text { Cleome lutea } \\
\text { population }\end{array}$ \\
\hline & $\begin{array}{c}\text { Cub Creek - Long } \\
\text { Draw } \\
\end{array}$ & June 1-3, 2006 & $\begin{array}{c}\text { Portions of dozen } \\
\text { sections in the area }\end{array}$ & No new occurrences \\
\hline & Hollenbeck Draw & June 30, 2005 & T9S, R22E, sec 9 & $\begin{array}{l}\text { Revisited Mentzelia } \\
\text { pumila occurrence }\end{array}$ \\
\hline & $\begin{array}{l}\text { Mill Draw - Ruby } \\
\text { Creek Areas (East } \\
\text { slope Beartooth) }\end{array}$ & June 4, 2006 & $\begin{array}{c}\text { Scattered sec in } \\
\text { T9S, R20E } \\
\text { T9S, R21E }\end{array}$ & No new occurrences \\
\hline & $\begin{array}{l}\text { Grove Creek (East } \\
\text { slope Beartooth) }\end{array}$ & $\begin{array}{c}\text { August 16-18, } \\
2006\end{array}$ & $\begin{array}{c}\text { T8S, R20E, sec 25, } \\
26,35\end{array}$ & $\begin{array}{l}\text { new occurrence of } \\
\text { Haplopappus } \\
\text { carthamoides var. } \\
\text { subsquarrosus }\end{array}$ \\
\hline & $\begin{array}{c}\text { South Fork Bridger } \\
\text { Creek }\end{array}$ & June 30, 2005 & $\begin{array}{l}\text { T7S, R24E, sec } 19 \\
\& 20\end{array}$ & $\begin{array}{l}\text { Revisited Mentzelia } \\
\text { pumila occurrence }\end{array}$ \\
\hline \multirow{5}{*}{ Carter } & Soda Lakes & July 20, 2005 & T1S, R58E, sec 26 & No new occurrences \\
\hline & $\begin{array}{l}\text { Powderville Road - } \\
\text { Hell Creek Formation }\end{array}$ & July 21-22, 2005 & T1S, R55E, sec 4, 9 & $\begin{array}{c}\text { Eriogonum visheri } \\
\text { population resurveyed } \\
2 \text { new locations of } \\
\text { Physaria brassicoides }\end{array}$ \\
\hline & Keith Creek & July 21, 2005 & T3S, R56E, sec 23 & No new occurrences \\
\hline & $\begin{array}{l}\text { Cottonwood Creek - } \\
\text { Dead Horse Point }\end{array}$ & June 26, 2006 & $\begin{array}{c}\text { Scattered sec in } \\
\text { T6S, R58 \& 59E } \\
\text { T7S, R59E } \\
\text { T8S, R59E } \\
\end{array}$ & No new occurrences \\
\hline & $\begin{array}{c}\text { Dead Boy Creek - } \\
\text { Lone Tree Creek }\end{array}$ & July 20-21, 2005 & T2S, R58E & No new occurrences \\
\hline Custer & Strawberry Hill & July 19, 2005 & $\begin{array}{c}\text { T8N, R48E sec 23- } \\
24\end{array}$ & $\begin{array}{c}1 \text { new occurrence of } \\
\text { Physaria brassicoides } \\
\text { located on adjacent } \\
\text { private land }\end{array}$ \\
\hline \multirow[t]{4}{*}{ Powder River } & $\begin{array}{l}\text { Boxelder Creek - Bales } \\
\text { Creek - Bear Creek }\end{array}$ & $\begin{array}{c}\text { June } 28 \& 29, \\
2005 \text { and June 22, } \\
2006\end{array}$ & $\begin{array}{c}\text { T9S, R45E, sec 12, } \\
\text { 13, } 24 \\
\text { T9S, R46E, sec 6, 7, } \\
18 \\
\end{array}$ & No new occurrences \\
\hline & $\begin{array}{c}\text { Trail Creek (NW of } \\
\text { Moorhead) }\end{array}$ & July 24, 2005 & $\begin{array}{l}\text { T9S, R47E, sec } 1 \\
\text { T9S, R48E, sec } 6\end{array}$ & No new occurrences \\
\hline & Kelsey Hill & July 24, 2005 & T9S, R48E, sec 17 & No new occurrences \\
\hline & Spear Hills & June 24, 2006 & $\begin{array}{l}\text { T9S, R48E, sec 30- } \\
32\end{array}$ & $\begin{array}{c}\text { Failed to relocate } \\
\text { Physaria brassicoides } \\
\text { occurrence }\end{array}$ \\
\hline
\end{tabular}




\begin{tabular}{|c|c|c|c|c|}
\hline County & Survey Sites & Survey Date & $\begin{array}{c}\text { BLM Sections } \\
\text { Surveyed } \\
\end{array}$ & Results \\
\hline & $\begin{array}{c}\text { Jenkins Creek - Buffalo } \\
\text { Creek WSA }\end{array}$ & June 23, 2006 & $\begin{array}{l}\text { T8S, R48E, sec } 28 \\
\text { se1/4, 33, } 34\end{array}$ & $\begin{array}{c}\text { Cirsium } \\
\text { pulcherrimum, a new } \\
\text { Species of Concern for } \\
\text { Montana documented; } \\
\text { new species of } \\
\text { Boisduvalia } \\
\text { potentially } \\
\text { documented (ID } \\
\text { requires verification) }\end{array}$ \\
\hline & $\begin{array}{c}\text { Bootjack Draw - } \\
\text { Buffalo Creek WSA }\end{array}$ & $\begin{array}{l}\text { July 25, } 2005 \text { and } \\
\text { June 24, } 2006\end{array}$ & $\begin{array}{c}\text { T8S, R48E, sec 9- } \\
11,14\end{array}$ & $\begin{array}{c}\text { Cirsium } \\
\text { pulcherrimum, a new } \\
\text { Species of Concern for } \\
\text { Montana documented }\end{array}$ \\
\hline & Prong Creek & July 25, 2005 & $\begin{array}{l}\text { T7S, R48E, sec } 13 \\
\text { T7S, R49E, sec } 18\end{array}$ & No new occurrences \\
\hline & $\begin{array}{l}\text { Belle Creek - Pine } \\
\text { Creek }\end{array}$ & June 25, 2006 & $\begin{array}{l}\text { T7S, R53E, sec 17, } \\
\text { 18, 20, 21, 28, 29, } \\
33\end{array}$ & No new occurrences \\
\hline Prairie & $\begin{array}{l}\text { Big Sheep Mountains } \\
\text { Little Sheep Mountains }\end{array}$ & July 18-26, 2005 & $\begin{array}{c}\text { Scattered sec in } \\
\text { T15N, R46E } \\
\text { T15N, R47E } \\
\text { T15N, R48E } \\
\text { T14N, R46E } \\
\text { T14N, R48E } \\
\text { T14N, R48E } \\
\text { T14N, R50E } \\
\text { T13N, R46E } \\
\text { T13N, R47E } \\
\text { T13N, R48E }\end{array}$ & No new occurrences \\
\hline
\end{tabular}




\section{DISCUSSION AND RECOMMENDATIONS}

Future surveys on BLM lands within the study area are likely to find additional occurrences of vascular plant Species of Concern, BLM

Sensitive plant species and even additions to the known flora of the state. Though this study increases the knowledgebase of information in regards to rare plants in the study area, it, as well as any other survey effort that covers very large geographic areas, is neither definitive nor comprehensive.

The 2006 field season ended up to be suboptimal for the survey of many SOC in the area as it was a "dry" year, or at least precipitation did not fall during time periods that would result in "good" growth for many plant species. For instance, Astragalus grayi plants were observed to be mostly in non-flowering condition in 2006, and Cleome lutea which flowered profusely in 2005 could not be relocated the following season in the same vicinity. In contrast, early season rains in 2005 resulted in favorable growing conditions during that year. However, the precipitation at times impeded travel as many roads in the study area are not drivable when wet due to the high clay content of many of the soils. Additionally, optimal survey times for individual species varies, so a single site visit to an area is apt to miss species that have not flowered or for which the morphological condition of the plants are no longer adequate for identification.

\section{Future Survey and Monitoring Recommendations}

Initiate monitoring of populations of BLM Sensitive plants. The current lack of monitoring data for most, if not all, BLM Sensitive and Montana SOC plants in the project area severely limits any conservation and management recommendations that can be made for particular species, landscapes or watersheds. Additionally, more comprehensive survey efforts that include federal, state and private lands may show that certain taxa are more abundant than previously thought and not in need of conservation measures or protection. The specific need is for annual or other semi-regular monitoring of a subset of SOC populations for the purpose of monitoring trends and changes in land management. The general surveys conducted as part of this project, as well as most of the others mentioned previously, do not provide the depth of information required to make firm conclusions or recommendations about a species' ecology or management.

BLM lands surrounding Soda Lakes warrant additional surveys for plants listed as either BLM Sensitive or Montana SOC. A single visit to the area in 2005 did not adequately survey the area in extent or in terms of vegetation phenology. The isolated and patchy nature of BLM lands surrounding the lakes, particularly the northern lake, complicates surveying the area.

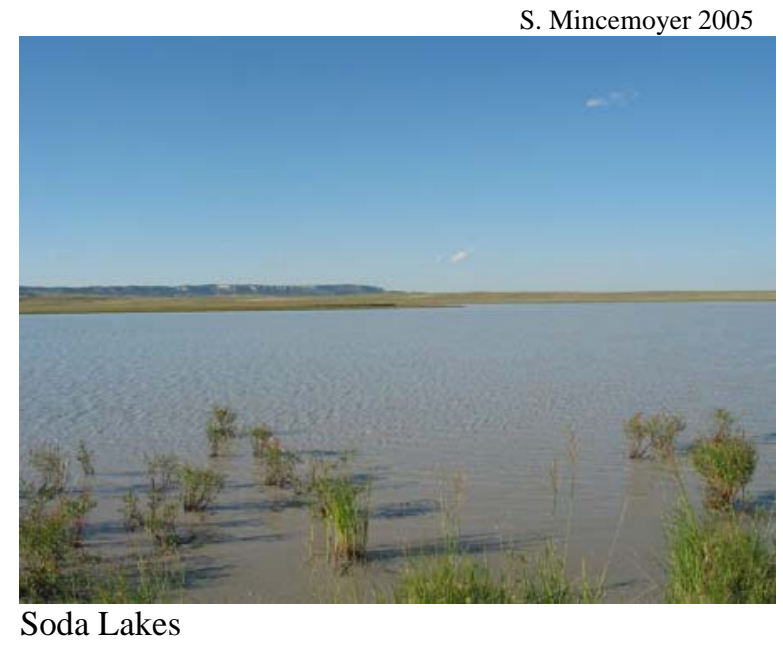

BLM lands encompassing the Terry Badlands still require surveys for plant SOC and BLM Sensitive plants. The area may include suitable habitat for species such as Astragalus barrii and Physaria brassicoides, as well as other rare plants.

Additional surveys for Astragalus barrii are needed. Surveys during 2005-2006 generally took place too late in the growing season for identification of the species. Surveys during mid-May to the beginning of June when the species is in flower are required to separate it 
from the closely related A. gilviflorus and A. hyalinus which are common in portions of the study area, and grow in the same habitats as $A$. barrii. Surveys for this species are needed on federal, state and private ownerships to determine its abundance and population numbers in the state. Suitable habitat for the species appears to be plentiful in eastern Montana and it is possible that additional surveys on multiple ownerships may find the species to be more abundant than previously known and possibly determine that the species is not in need of any special conservation measures or designation. Upcoming predictive modeling work will help define and map potentially suitable habitat for the species which should help greatly in guiding future survey efforts.

Monitoring of the population dynamics for Haplopappus carthamoides var. subsquarrosus on BLM and National Forest lands is needed. Limited data between the two survey years of 1995 and 2006 shows a drastic decline in numbers. However, this observation is limited to surveys on only three populations. Additional monitoring will be needed to determine if this is a temporary reduction, possibly related to drought conditions in the Carbon County area, part of normal temporal population fluctuations, or if other factors are at play.

Additional surveys and better documentation of existing populations of Sphaeromeria capitata on federal ownerships are needed to properly review the global and state ranks for this species. Surveys are needed in Beaverhead, Big Horn and Carbon Counties. Though the global rank is currently a G3, better documentation of the species' range and abundance is likely to find that a G4 rank is more appropriate. No change in rank is proposed at this time.

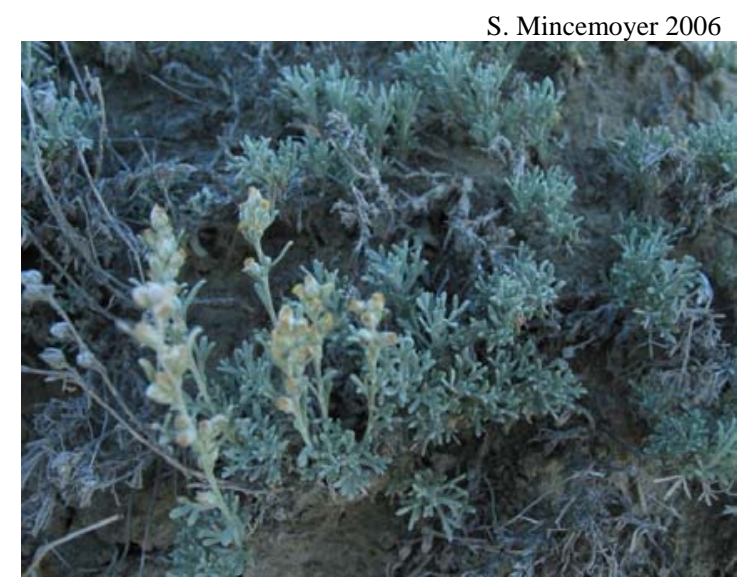

Sphaeromeria capitata growing on the lower slopes of the Pryor Mountains

Surveys for Aster glaucodes (gray aster) are needed in the Pryor Mountain area to provide increased documentation on population levels and geographic distribution of the species to support the state rank of the species. The species is currently ranked S3 in Montana though available data do not conclusively support such a rank and it is unclear as to whether additional data would support the current rank. A rank of S2 for the species may be more appropriate. Suitable habitat on National Forest, BLM and National Park Service lands should be surveyed. No change in rank is proposed at this time.

\section{BLM Status Recommendations}

Recommend the removal of Dichanthelium oligosanthes var. scribnerianum from the BLM Sensitive Plant Species List. The species has not been conclusively documented from BLM lands to date. Reports of the species on BLM lands from MTNHP data are due to the large imprecision associated with the mapping of historical collections with imprecise locality data. Suitable habitat for the species on BLM lands is likely very limited in extent.

Recommend the removal of Amorpha canescens from the BLM Sensitive Plant Species List. The species has not been conclusively documented from BLM lands to date. Reports of the species on BLM lands from MTNHP data are due to the large imprecision associated with the mapping of historical collections with vague locality data. 
Recommend the removal of Potentilla plattensis from the BLM Sensitive Plant Species List. The species has not been conclusively documented from BLM lands to date. Reports of the species on BLM lands from MTNHP data are due to the large imprecision associated with the mapping of historical collections with vague locality data. Suitable habitat for the species on BLM lands is likely very limited in extent.

Recommend the removal of Eleocharis rostellata from the BLM Sensitive Plant Species List. The species had been listed as occurring on BLM lands due to an incorrectly mapped occurrence at the Bluewater Fish Hatchery near Bridger. This error was noticed as part of the review of all mapped occurrences on the two Field Offices that was previously mentioned. At this time, there are no known occurrences of the species on BLM lands in Montana. Suitable habitat for the species on BLM lands is likely very limited in extent.

Recommend the removal of Sullivantia hapemanii from the BLM Sensitive Plant Species List. The species is not known to occur on BLM lands in Montana. The species is known from seeps and springs generally along canyon walls in the Bighorn canyon area. Suitable habitat for the species on BLM lands is likely very limited in extent if present at all.

Recommend the addition of Cirsium pulcherrimum to the BLM Sensitive Plant Species List. This species was located on BLM lands in Montana for the first time during the course of this project. The species was found in or near the Buffalo Creek Wilderness Study Area where it was observed in only a couple locations with few, individual plants. It can be considered rare in the state at this time and will receive a state rank of $\mathrm{S} 1$.

\section{Heritage Status Recommendations and Changes}

A change in the state rank of Cirsium pulcherrimum from SU to S1. See comments above.
A change in the state rank in June 2006 for Artemisia pedatifida from S3 to S4, thus removing it from any further tracking by MTNHP at this time due to its abundance in the Big Horn Basin/Pryor Mountain Desert of Carbon County. In fact, the species is a dominant species throughout large portions of this area. This status change is supported in part by the previous work of Lesica and Achuff (1992a).

A change in the state rank in June 2006 for Platyschkuhria integrifolia (basindaisy) from S3 to S3S4, thus removing it from any further tracking by MTNHP at this time due to its abundance in the Big Horn Basin/Pryor Mountain Desert of Carbon County. This change is supported by the previous work of Lesica and Achuff (1992a) who reported 58 "populations" and that the species is "abundant throughout much of the study area.”

A change in the state rank in June 2006 for Xylorhiza glabriuscula (smooth woodyaster) from S3 to S4, thus removing it from any further tracking by MTNHP at this time due to its abundance in the Big Horn Basin/Pryor Mountain Desert of Carbon County. This change is supported by the previous work of Lesica and Achuff (1992a) who reported 26 large "populations" and that the species is "common in the study area."

A change in the state rank for Haplopappus multicaulis (branched goldenweed) from S3 to S3S4 thus removing it from any further tracking by MTNHP at this time due to its abundance in Carter County and apparent lack of threats. Though the species has a limited distribution in Montana, it is common in portions of the county, including along some roadsides on BLM lands.

A change in the state rank for Eriogonum brevicaule var. canum from S3 to S3S4 and removal from further tracking by the MTNHP. It is recommended that the global rank be changed accordingly from G3 to G3G4 or G4. The Wyoming Natural Diversity Database has global rank responsibility for this taxon and the recommendation has been passed along to that 
program. The abundance of the taxon in Montana has been previously documented by Lesica and Achuff (1992a, b) and by Heidel and Fertig (2000). Both of these reports recognize the number of large populations of the species and the apparent lack of threats to the species' viability. Heidel and Fertig (2000) also state that "No special management is required to ensure the survival of the species."

\section{Additional Recommendations and Discussion}

One taxon currently listed as BLM Sensitive and as a Montana SOC, Physaria didymocarpa var. lanata, may be of questionable morphological recognition. A recent review of all $P$. didymocarpa collections at MONTU by Peter Lesica noted that the character (spreading leaf trichomes) by which variety lanata is distinguished appears to be continuous and not readily distinct (Lesica, pers. comm. 2006). Additional study and information will be needed before any change in status is made or recommended.

Information on the biology, ecology, rank factors and management implications as they pertain to individual Species of Concern can be found on the MTNHP's web-based Rare Plant Field Guide (www.mtnhp.org).

\section{Priority Areas}

Several areas of BLM lands in the project area are of note due to the diversity and/or abundance of one or more BLM Sensitive, Montana SOC or other plants of limited distribution.

Pryor Mountain Desert: The Pryor Mountain Desert - Bighorn Basin area contains one of the most unique floras in the state and hosts several state and globally rare vascular plant taxa (Lesica and Achuff 1992a). Additionally, the area provides critical habitat for several animal species of significance in Montana including the Black-throated Gray Warbler, Blue-gray Gnatcatcher, white-tailed prairie dog and the pallid bat (Hendricks 2004, Hendricks et al. 2004, Wilson 1996, MTNHP
2006). As such, appropriate management of the area to maintain viable populations, intact habitats and ecosystem processes is critical to the survival of many species in the state. This area encompasses lands generally south of National Forest lands in the Pryors to the Montana-Wyoming border, and west to Highway 310 and east to the Bighorn Canyon NRA. The habitats of this area contain a significant proportion of the overall range and/or populations of numerous plant species that are listed as BLM Sensitive, Montana SOC or are otherwise rare or of limited distribution. Included in this category are plants such as Artemisia pedatifida, Astragalus geyeri, Astragalus grayi, Astragalus oreganus, Camissonia andina, Camissonia parvula, Erigeron allocotus, Eriogonum brevicaule var. canum, Grayia spinosa, Leptodactylon caespitosum, Lesquerella lesicii, Malacothrix torreyi, Mentzelia pumila, Nama densum, Penstemon laricifolius, Platyschkuhria integrifolia, Sphaeromeria capitata, Stanleya tomentosa (woolly princesplume) and Townsendia spathulata.

S. Mincemoyer 2006

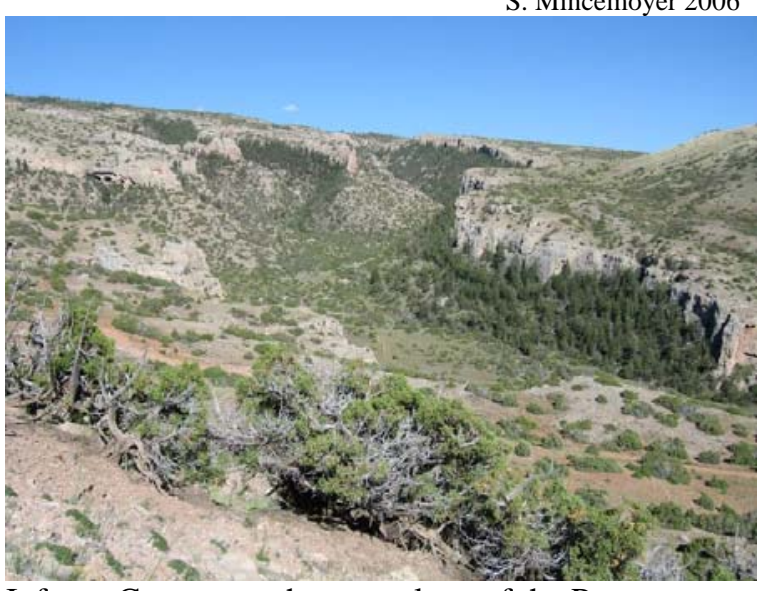

Inferno Canyon on the west slope of the Pryor Mountains

The importance of this area to numerous plant species of significance is hard to overemphasize and it is perhaps second in importance statewide only to areas of Beaverhead County.

Meeteetse Spires-Grove Creek: The Meeteetse Spires and surrounding BLM lands on the east flank of the Beartooth Plateau are 
known to contain two vascular plant taxa of significance, Shoshonea pulvinata and Haplopappus carthamoides var. subsquarrosus. Both taxa are globally rare and are endemic to south-central Montana and adjacent Wyoming. The Shoshonea occurrence is one of only five known from Montana. BLM, state and private lands are interspersed in the area resulting in potentially conflicting resource management objectives. The core of this area encompasses only about six square miles immediately adjacent to National Forest land. A second area immediately to the south along the Wyoming border and adjacent to National Forest land contains significant populations of $H$.

carthamoides var. subsquarrosus in an area of mixed BLM and private ownerships.

S. Mincemoyer 2006

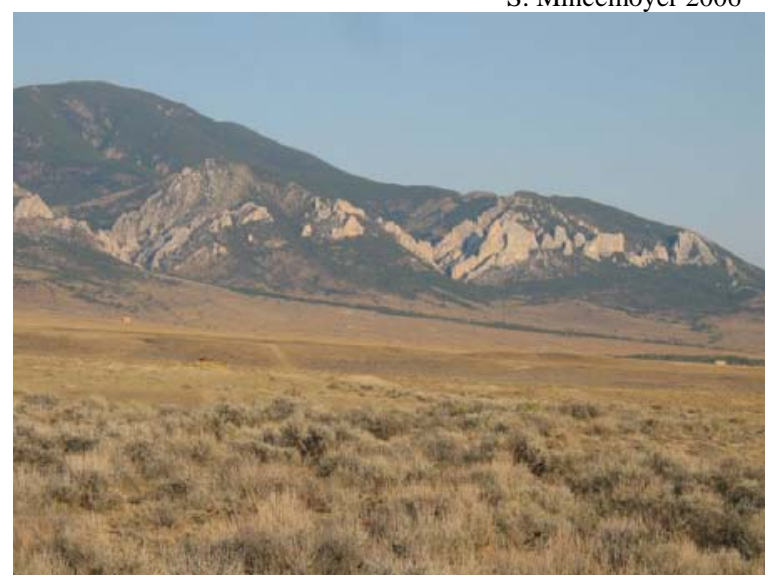

Grove Creek drainage and the Meeteetse Spires along the east flank of the Beartooth Plateau
Biddle-Belle Creek: BLM lands in the Biddle-Belle Creek area cover several thousand acres though they are scattered in distribution. This area contains some of the most important habitat for the globally rare Astragalus barrii. BLM and private lands in the area contain perhaps the densest concentration of populations of this species range-wide. Any detrimental change in land management or alterations of the habitat that would result in adverse effects to this metapopulation is likely to result in significant impacts to the species' long-term viability in the region.

S. Mincemoyer 2006

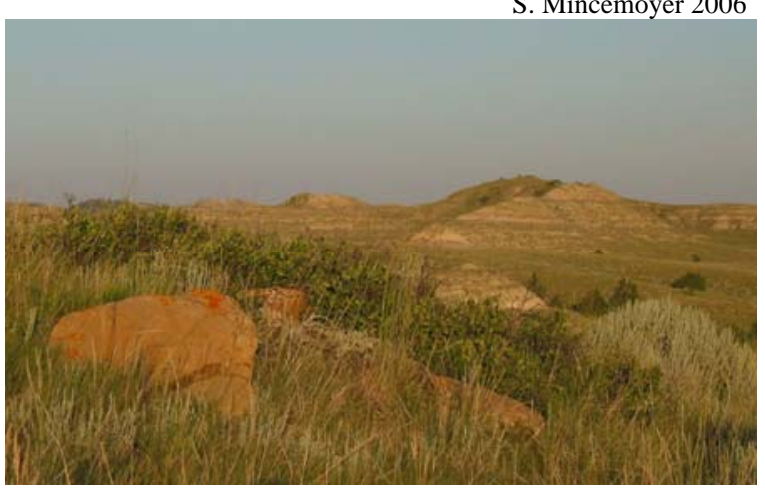

Belle Creek Drainage 


\section{REFERENCES}

Barton, D. and S. Crispin. 2003. Globally significant plants in southeastern Big Horn and southwestern Rosebud counties, Montana. Montana Natural Heritage Program, Helena, MT. 26 pp. + app.

Bureau of Land Management. 2005. Montana/Dakotas BLM Sensitive Plant Species List. Montana State Office, Billings, MT. 9 pp.

Carlson, J. C. and S. V. Cooper. 2003. Plant and animal resources and ecological condition of the Hanging Woman Basin in Big Horn County, Montana and Sheridan County, Wyoming. Montana Natural Heritage Program, Helena, MT. 25 pp. + app.

Dorn, R. D. 2001. Vascular plants of Wyoming Third Edition. Mountain West Publishing, Cheyenne, Wyoming. $412 \mathrm{pp}$.

Dorn, R. D. 1984. Vascular plants of Montana. Mountain West Publishing, Cheyenne, Wyoming. $276 \mathrm{pp}$.

Great Plains Flora Association. 1986. Flora of the Great Plains. University of Kansas Press. Lawrence, Kansas.

Heidel, B. 2001. Monitoring Shoshonea pulvinata in the Pryor and Beartooth Mountains, Carbon County, Montana. 1999 Trend Report to the Bureau of Land Management, MT. Montana Natural Heritage Program, Helena, MT. 11 pp. + app.

Heidel, B. 1997. Preliminary Botanical Survey of the Tongue River Area. Unpublished Report to Montana Department of Environmental Quality. Montana Natural Heritage Program, Helena, MT. $11 \mathrm{pp}+\mathrm{app}$.

Heidel, B. 1993. Survey for Quercus macrocarpa in the Powder River Resource Area, Miles City District, Bureau of Land Management, Montana. Montana Natural Heritage Program, Helena, MT. 12 pp. + app.
Heidel, B. L. and K. H. Dueholm. 1995. Sensitive plant survey in the Sioux District, Custer National Forest: 1994; Carter County, Montana and Harding County, South Dakota. Unpublished report to the Custer National Forest. Montana Natural Heritage Program, Helena. 95 pp. + app.

Heidel, B. and W. Fertig. 2000. Rare Plants of Bighorn Canyon National Recreation Area. Report to the National Fish and Wildlife Foundation and Bighorn Canyon National Recreation Area. Montana Natural Heritage Program, Helena and Wyoming Natural Diversity Database, Laramie. 63 pp. + app.

Heidel, B., C. Jean and S. Crispin. 2002. Plant Species of Concern and Plant Associations of Powder River County, Montana. Report to the Bureau of Land Management. Montana Natural Heritage Program, Helena, MT. 23 pp. + app.

Heidel, B. L. and H. Marriott. 1996. Sensitive plant species survey of the Ashland District, Custer National Forest, Powder River and Rosebud Counties, Montana. Unpublished report to the Custer National Forest. Montana Natural Heritage Program, Helena, MT. 94 pp. + app.

Hendricks, P. 2004. First nesting record of blackthroated gray warbler (Dendroica nigrescens) for Montana. Western North American Naturalist. Vol 64(4). October 2004. pp. 548-550.

Hendricks, P., C. Currier and J. Carlson. 2004. Bats of the BLM Billings Field Office in southcentral Montana, with emphasis on the Pryor Mountains. Report to the Bureau of Land Management. Montana Natural Heritage Program, Helena, MT. 19 pp. + app.

Keil, D. 2006. Cirsium. In: Flora of North America Editorial Committee, eds. 1993+. Flora of North America North of Mexico. 12+ vols. New York and Oxford. Vol. 19. pp. 95164. 
Lesica. P. 2003. Conserving globally rare plants on lands administered by the Dillon Office of the Bureau of Land Management. Report to the USDI Bureau of Land Management, Dillon Field Office. Montana Natural Heritage Program, Helena, MT. 22 pp. + app.

Lesica, P. 1995a. Conservation status of Haplopappus carthamoides var. subsquarrosus in Montana. Unpublished report to the US Forest Service and the Bureau of Land Management. Montana Natural Heritage Program, Helena, MT. 22 pp. + app.

Lesica, P. 1995b. Conservation status of Lesquerella lesicii in Montana. Unpublished report to the US Forest Service and the Bureau of Land Management. Montana Natural Heritage Program, Helena, MT. 16 pp. + app.

Lesica, P. and P. L. Achuff. 1992a. Distribution of vascular plant species of special concern and limited distribution in the Pryor Mountain Desert, Carbon County, Montana. Unpublished report to the Bureau of Land Management. Montana Natural Heritage Program, Helena, MT. 38 pp. + app.

Lesica, P. and P. L. Achuff. 1992b. Conservation status of Eriogonum x lagopus in southern Carbon County, Montana. Unpublished report to the Bureau of Land Management. Montana Natural Heritage Program, Helena, MT. 13 pp. + app.

Mincemoyer, S. 2005. Surveys of significant plant resources and related vegetation types for the Butte Office of the Bureau of Land Management. Report to the USDI Bureau of Land Management, Butte Field Office. Montana Natural Heritage Program, Helena, MT. 11 pp. + app.
Montana Natural Heritage Program. 2006. Biotics Database - December 2006. Helena, MT.

Schassberger, L. A. 1988. Status review of Astragalus barrii: USDA Forest Service Region 1, Custer National Forest, Montana. Unpublished report the USDA Forest Service. Montana Natural Heritage Program, Helena, MT. 21 pp. + app.

Shelly, J. S. 1988. Report on the Conservation status of Shoshonea pulvinata, a Candidate threatened species. Montana Natural Heritage Program, Helena, MT. 35 pp. + appendices.

Taylor, A. and R. Caners. 2002. Baseline survey for Astragalus barrii Barneby (Barr's milkvetch) and Physaria didymocarpa var. lanata A. Nels. (woolly twinpod) in eastern Big Horn and southwestern Rosebud counties, Montana. Report to the Bureau of Land Management. Montana Natural Heritage Program, Helena, MT. 8 pp. + app.

Vanderhorst, J., S. V. Cooper and B. L. Heidel. 1998. Botanical and vegetation surveys of Carter County, Montana. Unpublished report to the Bureau of Land Management. Montana Natural Heritage Program, Helena, MT. 116 pp. + app.

Wright, P. L. 1996. Status of rare birds in Montana, with comments on known hybrids. Northwestern Naturalist. Vol. 77(3). Winter 1996. pp. 57-85. 


\section{Appendix A. Global/State RANK Definitions}





\section{HERITAGE PROGRAM RANKS}

The international network of Natural Heritage Programs employs a standardized ranking system to denote global (range-wide) and state status. Species are assigned numeric ranks ranging from 1 to 5, reflecting the relative degree to which they are "at-risk". Rank definitions are given below. A number of factors are considered in assigning ranks - the number, size and distribution of known "occurrences" or populations, population trends (if known), habitat sensitivity, and threat. Factors in a species' life history that make it especially vulnerable are also considered (e.g., dependence on a specific pollinator).

GLOBAL RANK DEFINITIONS (NatureServe 2003)

G1 Critically imperiled because of extreme rarity and/or other factors making it highly vulnerable to extinction

G2 Imperiled because of rarity and/or other factors making it vulnerable to extinction

G3 Vulnerable because of rarity or restricted range and/or other factors, even though it may be abundant at some of its locations

G4 Apparently secure, though it may be quite rare in parts of its range, especially at the periphery

G5 Demonstrably secure, though it may be quite rare in parts of its range, especially at the periphery

T1-5 Infraspecific Taxon (trinomial) - The status of infraspecific taxa (subspecies or varieties) are indicated by a “T-rank” following the species' global rank

\section{STATE RANK DEFINITIONS}

S1

At high risk because of extremely limited and potentially declining numbers, extent and/or habitat, making it highly vulnerable to extirpation in the state

S2 At risk because of very limited and potentially declining numbers, extent and/or habitat, making it vulnerable to extirpation in the state

S3 Potentially at risk because of limited and potentially declining numbers, extent and/or habitat, even though it may be abundant in some areas

S4 Uncommon but not rare (although it may be rare in parts of its range), and usually widespread. Apparently not vulnerable in most of its range, but possibly cause for long-term concern

S5 Common, widespread, and abundant (although it may be rare in parts of its range). Not vulnerable in most of its range

\section{COMBINATION RANKS}

G\#G\# or S\#S\# Range Rank-A numeric range rank (e.g., G2G3) used to indicate uncertainty about the exact status of a taxon

\section{QUALIFIERS}

NR Not ranked

Q Questionable taxonomy that may reduce conservation priority-

Distinctiveness of this entity as a taxon at the current level is questionable; resolution of this uncertainty may result in change from a species to a subspecies or hybrid, or inclusion of this taxon in another taxon, with the resulting taxon having a lower-priority (numerically higher) conservation status rank 
$\mathrm{X}$

$\mathrm{H}$

$\mathrm{U}$

HYB

?

$\mathrm{C}$

A

Z

$\mathrm{P}$

$\mathrm{R}$

SYN

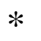

B

$\mathrm{N}$

Presumed Extinct-Species believed to be extinct throughout its range. Not located despite intensive searches of historical sites and other appropriate habitat, and virtually no likelihood that it will be rediscovered

Possibly Extinct - Species known from only historical occurrences, but may never-theless still be extant; further searching needed

Unrankable-Species currently unrankable due to lack of information or due to substantially conflicting information about status or trends

Hybrid-Entity not ranked because it represents an interspecific hybrid and not a species

Inexact Numeric Rank-Denotes inexact numeric rank

Captive or Cultivated Only_-Species at present is extant only in captivity or cultivation, or as a reintroduced population not yet established

Accidental-Species is accidental or casual in Montana, in other words, infrequent and outside usual range. Includes species (usually birds or butterflies) recorded once or only a few times at a location. A few of these species may have bred on the one or two occasions they were recorded

Zero Occurrences-Species is present but lacking practical conservation concern in Montana because there are no definable occurrences, although the taxon is native and appears regularly in Montana

Potential-Potential that species occurs in Montana but no extant or historic occurrences are accepted

Reported-Species reported in Montana but without a basis for either accepting or rejecting the report, or the report not yet reviewed locally. Some of these are very recent discoveries for which the program has not yet received first-hand information; others are old, obscure reports

Synonym - Species reported as occurring in Montana, but the Montana Natural Heritage Program does not recognize the taxon; therefore the species is not assigned a rank

A rank has been assigned and is under review. Contact the Montana Natural Heritage Program for assigned rank

Breeding-Rank refers to the breeding population of the species in Montana Nonbreeding - Rank refers to the non-breeding population of the species in Montana 
APPENDIX B. MAPS OF GENERAL SURVEY AREAS AND ROUTES LISTED BY COUNTY 



\section{Maps of General Survey Areas and Routes Listed by County}

Survey routes are provided to show general areas that were surveyed and are not intended to display detailed survey routes, nor are all BLM areas that were visited during this project shown in the maps below.

\section{LIST OF MAPS}

\section{Big Horn County:}

Map 1. Feeback Draw

\section{Carbon County:}

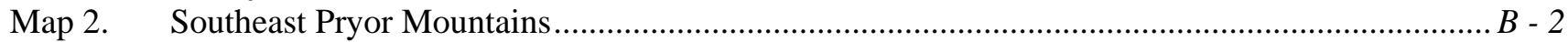

Map 3. Hollenbeck-Long-Williams Draws-Cub Creek .................................................................... $B$ - 3

Map 4. Grove Creek-Meeteetse Spires .......................................................................................... $B$

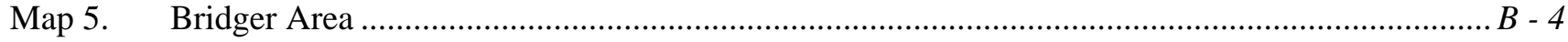

Map 6. HWY 310-Jack Creek south of Bridger............................................................................... $B-4$

\section{Carter County:}

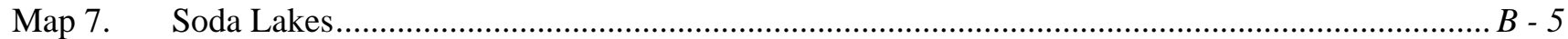

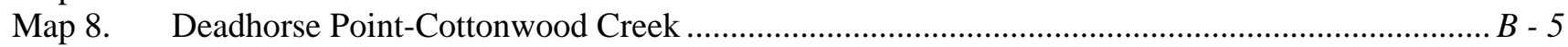

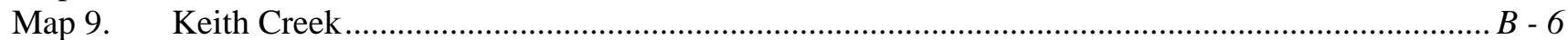

Map 10. Hell Creek Formation east of Powderville ......................................................................... $B$ - 6

\section{Custer County:}

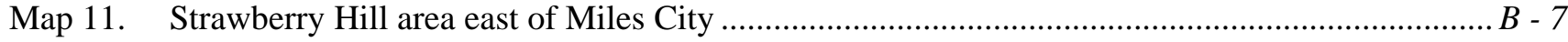

\section{Powder River County:}

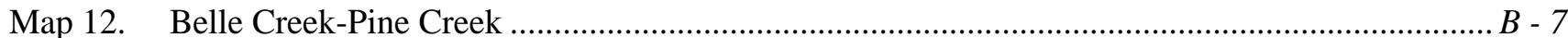

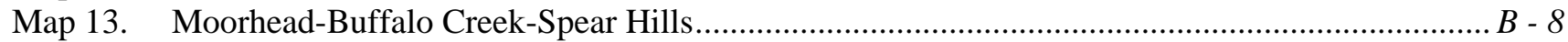

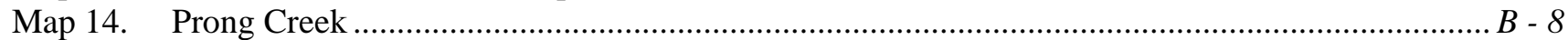

Map 15. Boxelder Creek-Bales Creek-Bear Creek …......................................................................... $B$ - 9

\section{Prairie County:}

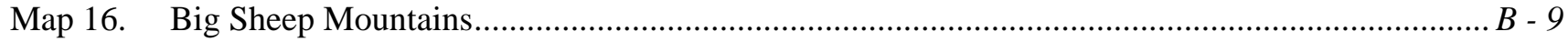

Map 17. Little Sheep Mountains ...................................................................................................... $B$ - 10

Map 18. Homestead and Innes Reservoirs ........................................................................................ $B$ - 10 


\section{Big Horn County}

Map 1. Feeback Draw.

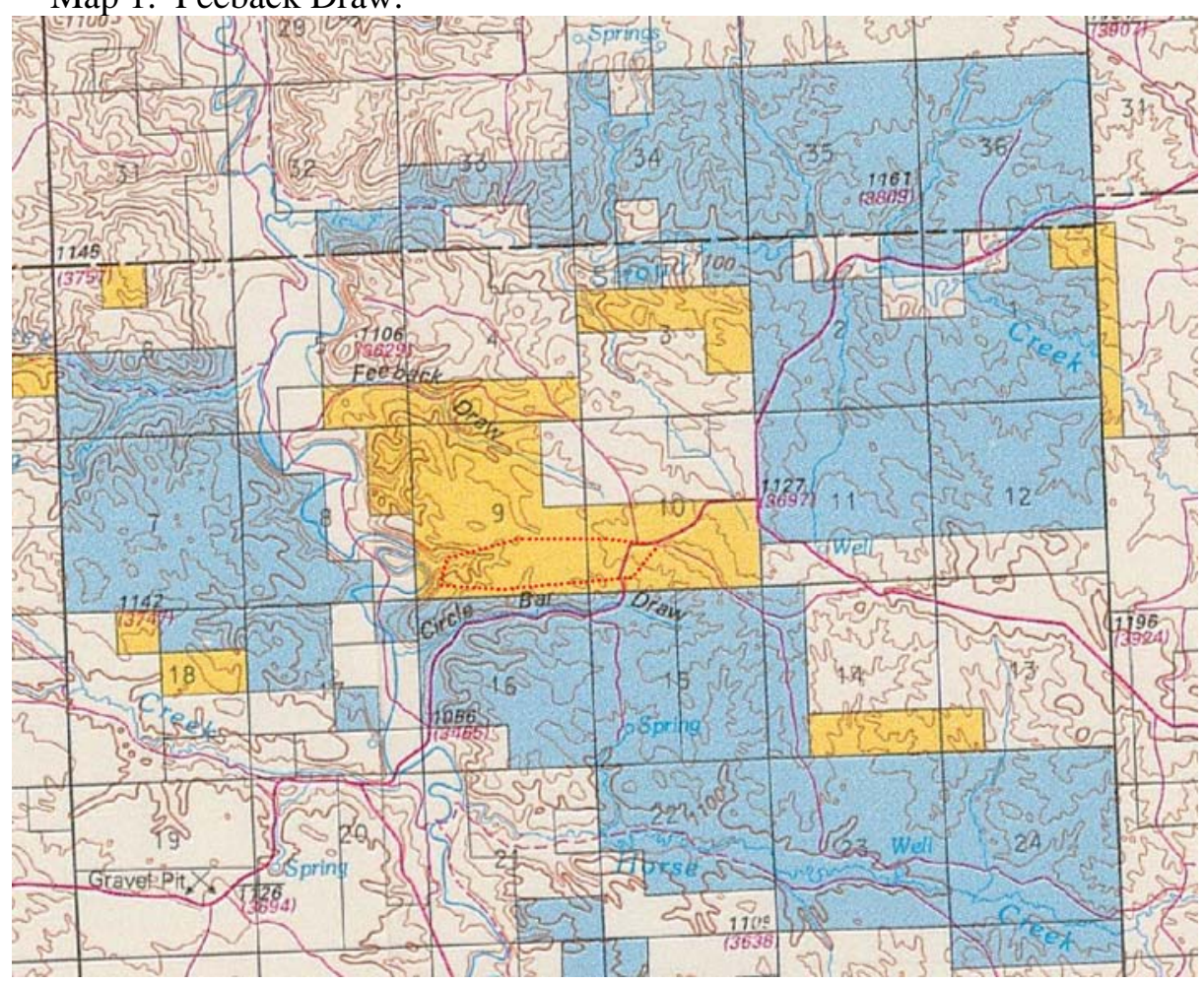

\section{Carbon County}

Map 2. Southeast Pryor Mountains.

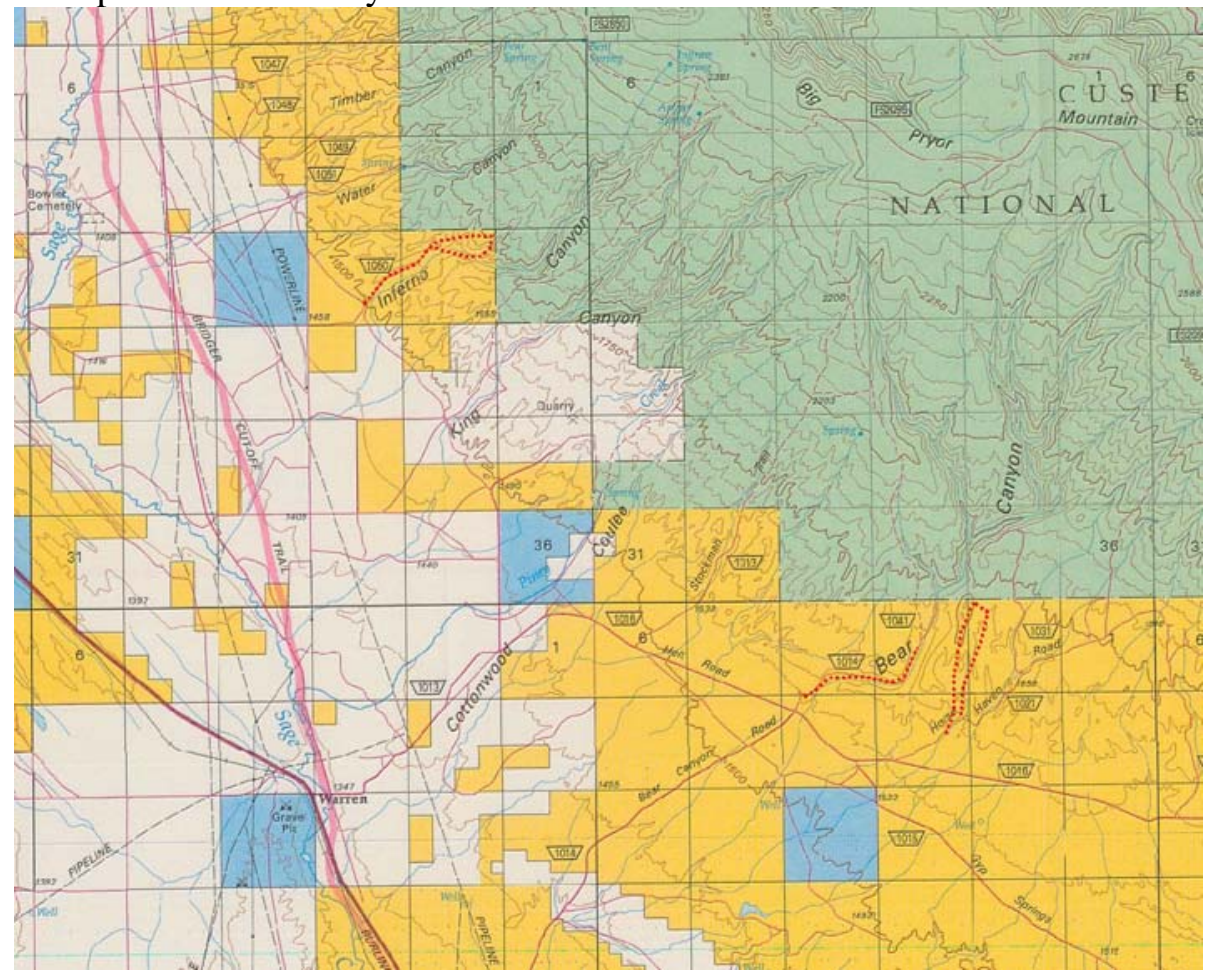


Map 3. Hollenbeck-Long-Williams Draws-Cub Creek.

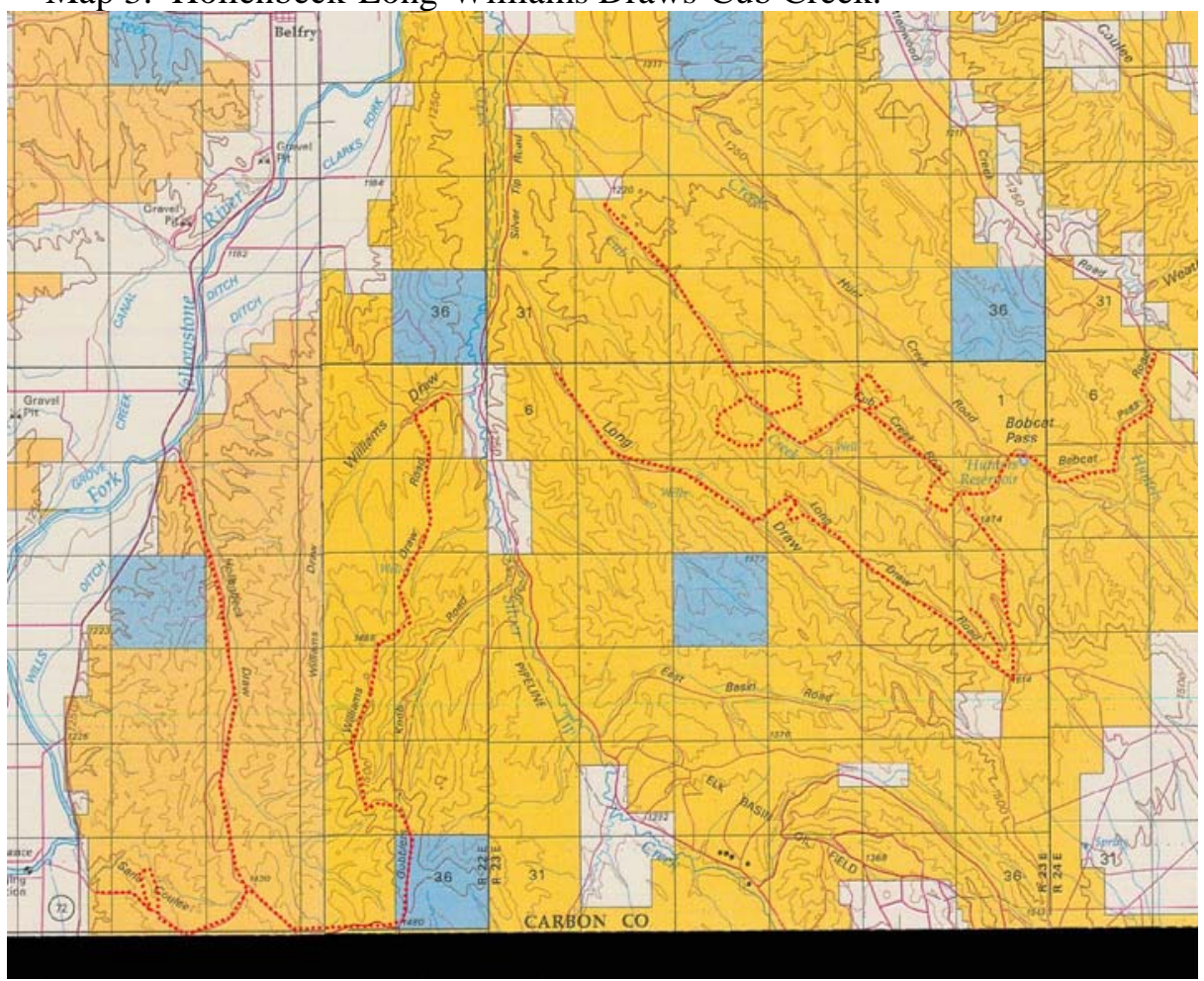

Map 4. Grove Creek-Meeteetse Spires.

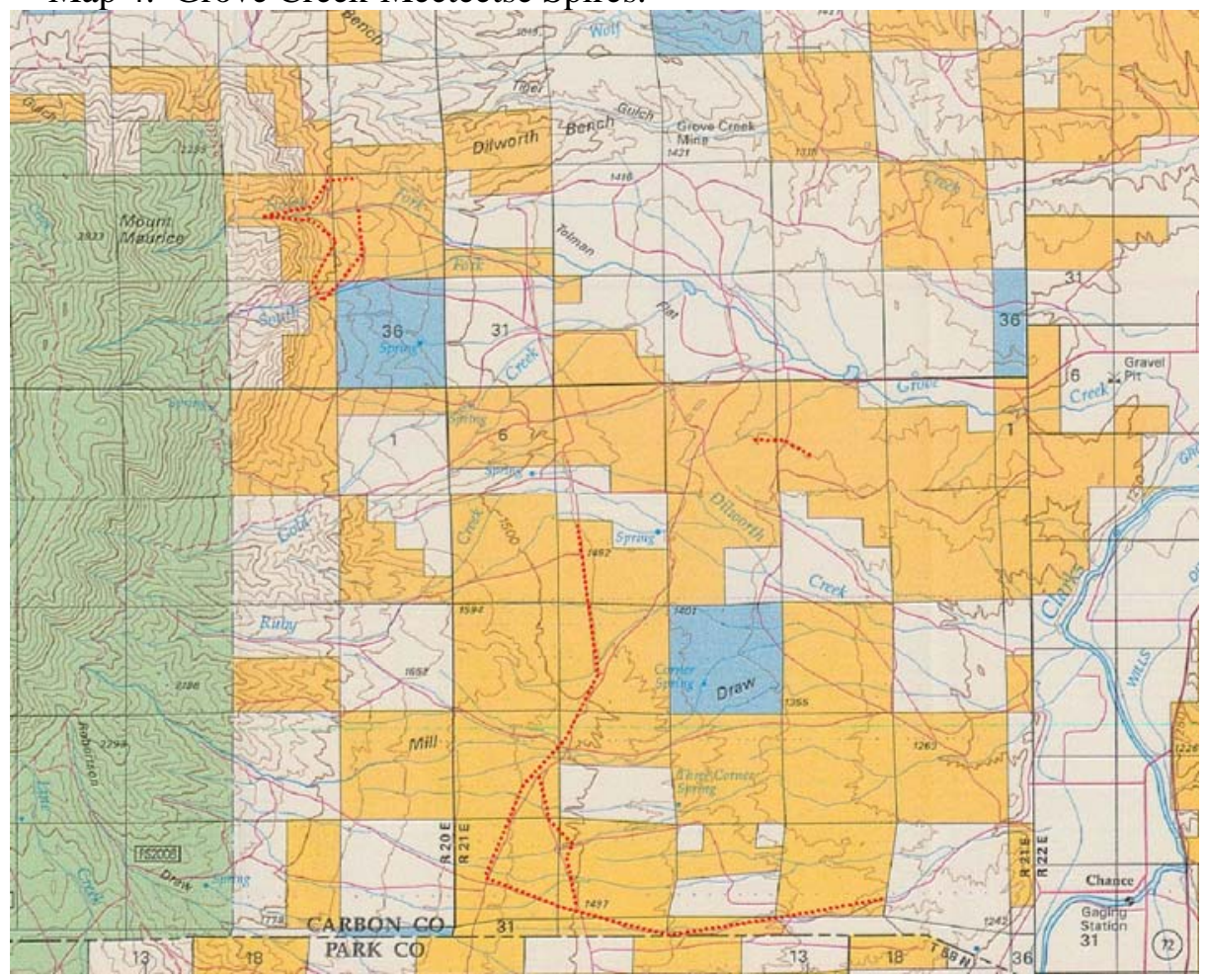

Appendix B - 3 
Map 5. Bridger Area.

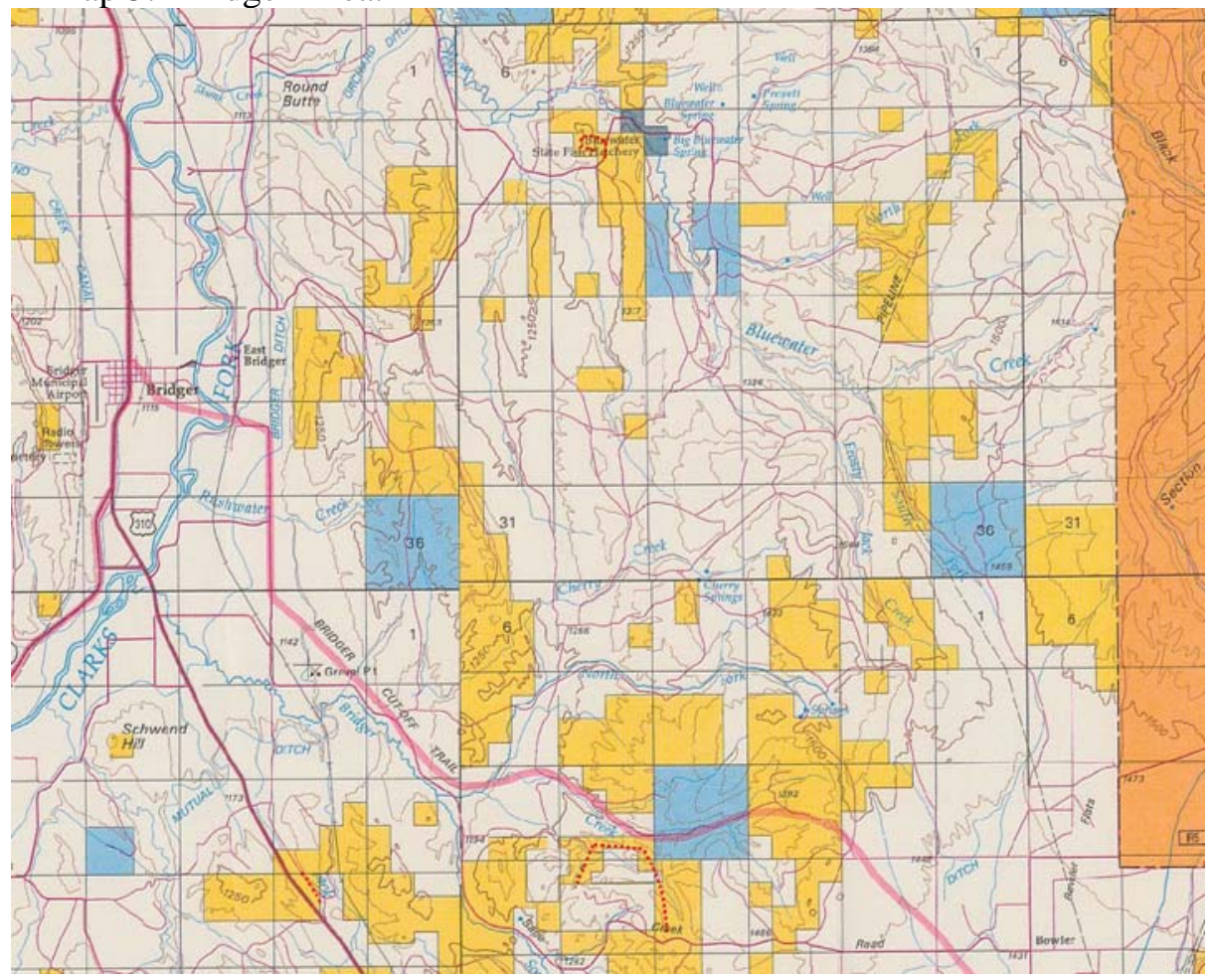

Map 6. HWY 310-Jack Creek south of Bridger.

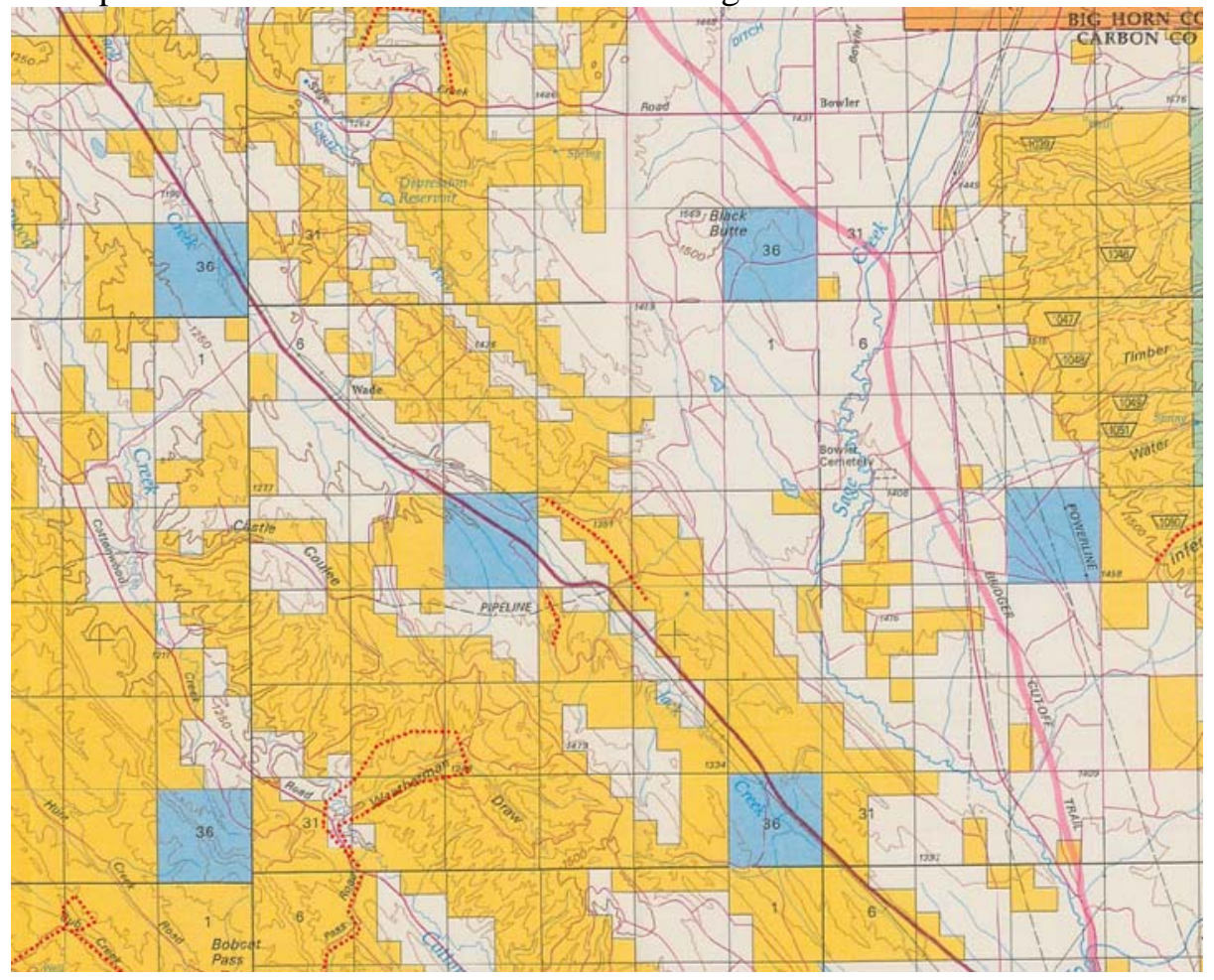




\section{Carter County}

Map 7. Soda Lakes.

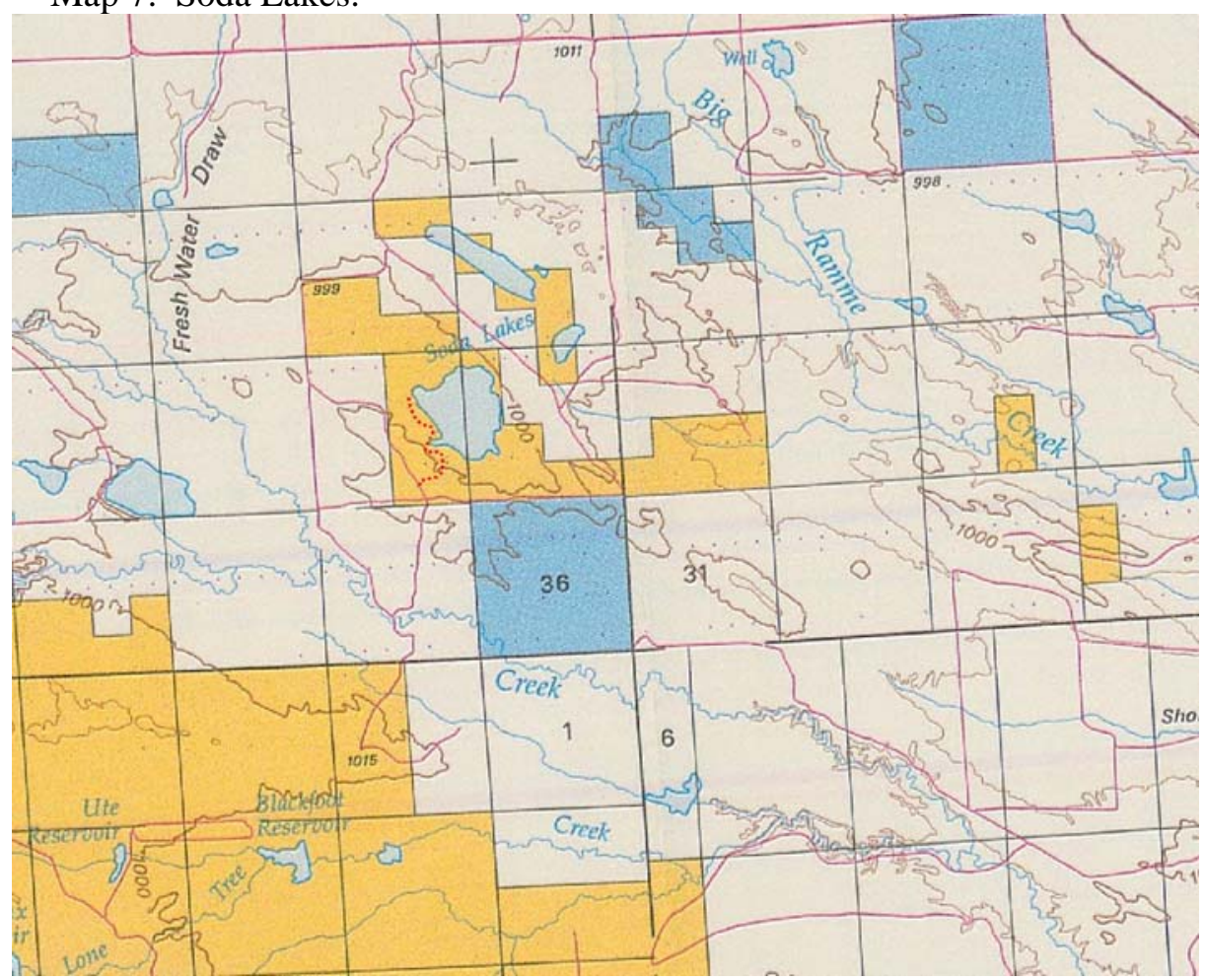

Map 8. Deadhorse Point-Cottonwood Creek.

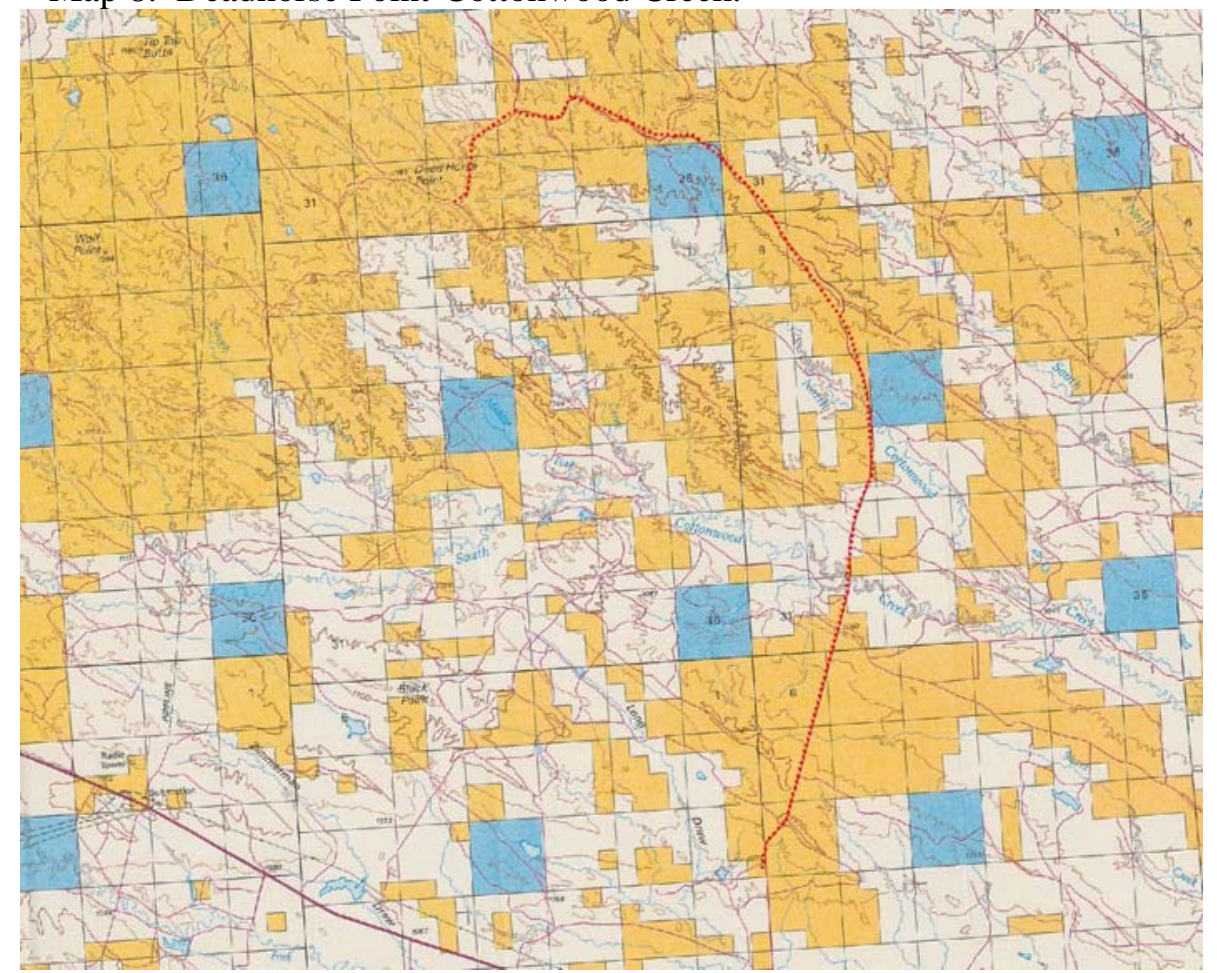

Appendix B - 5 
Map 9. Keith Creek.

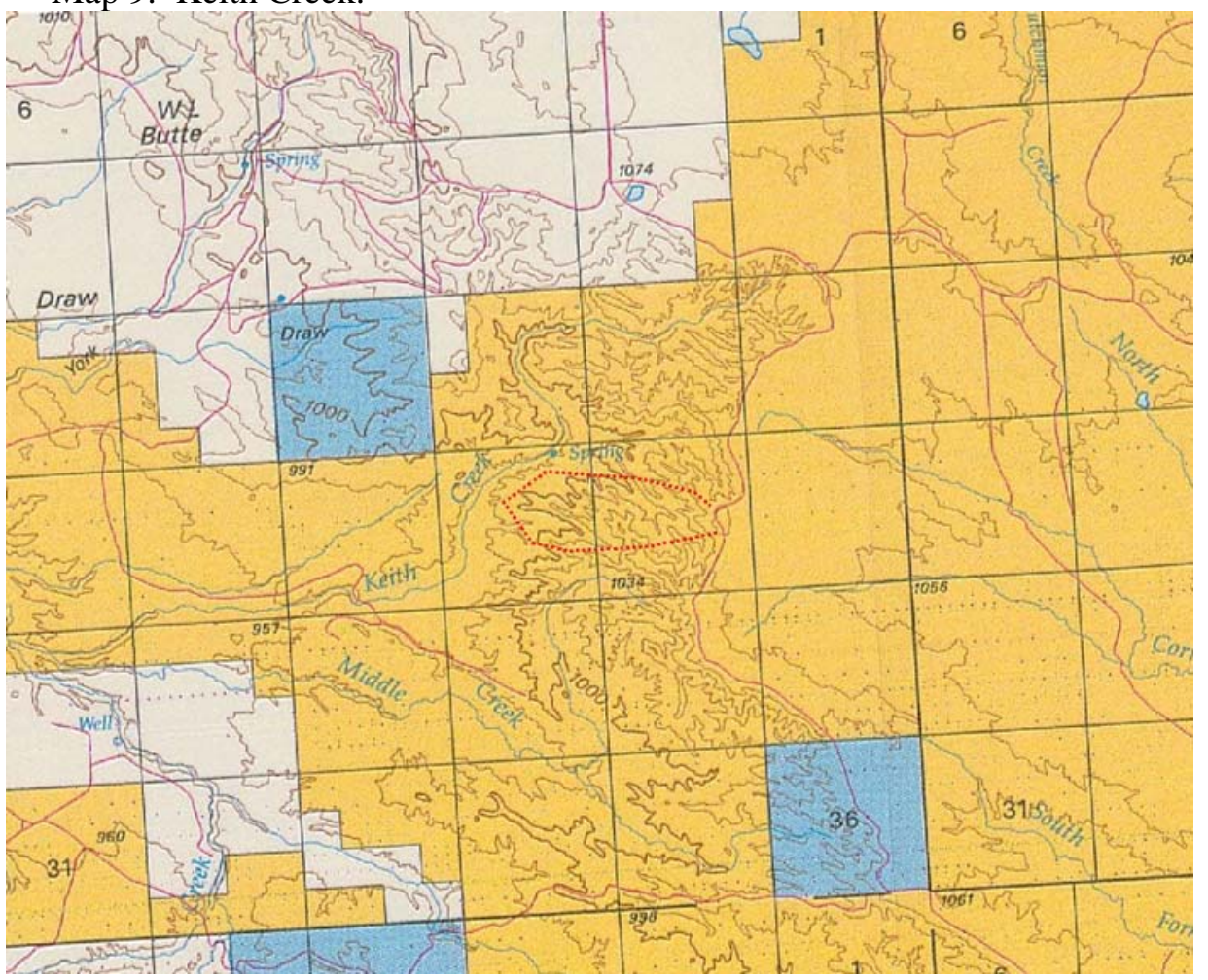

Map 10. Hell Creek Formation east of Powderville.

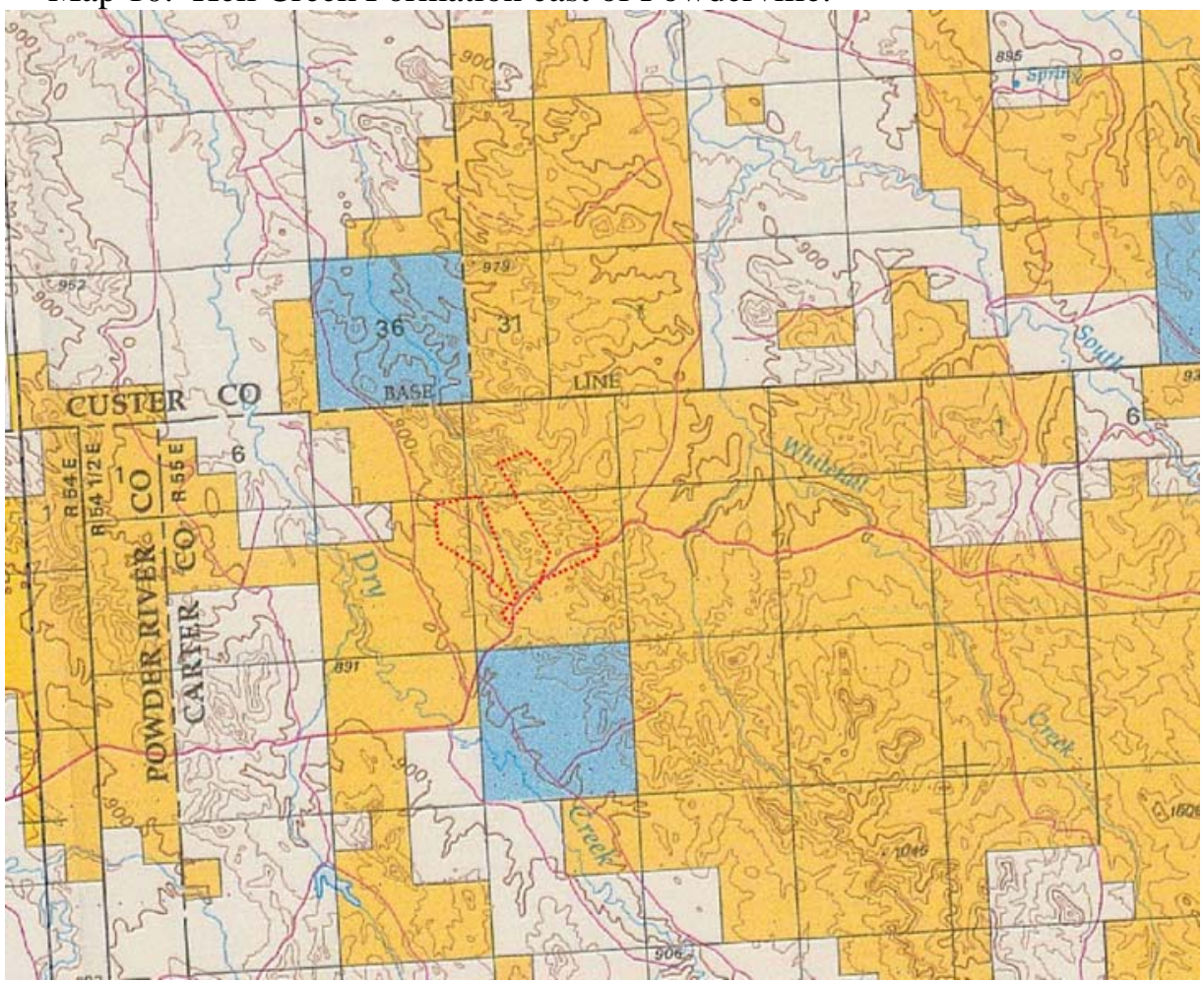




\section{Custer County}

Map 11. Strawberry Hill area east of Miles City.

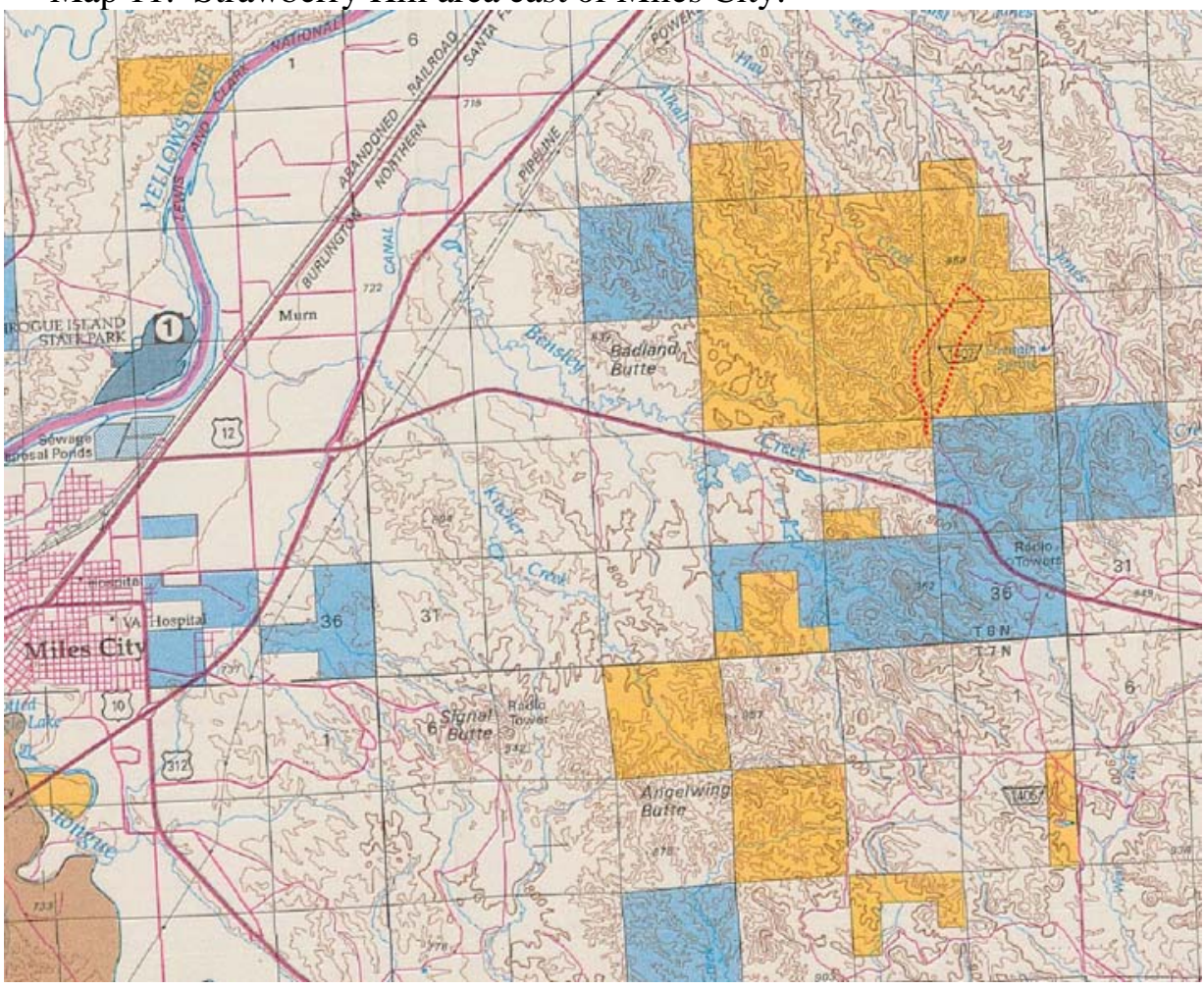

Powder River County

Map 12. Belle Creek-Pine Creek.

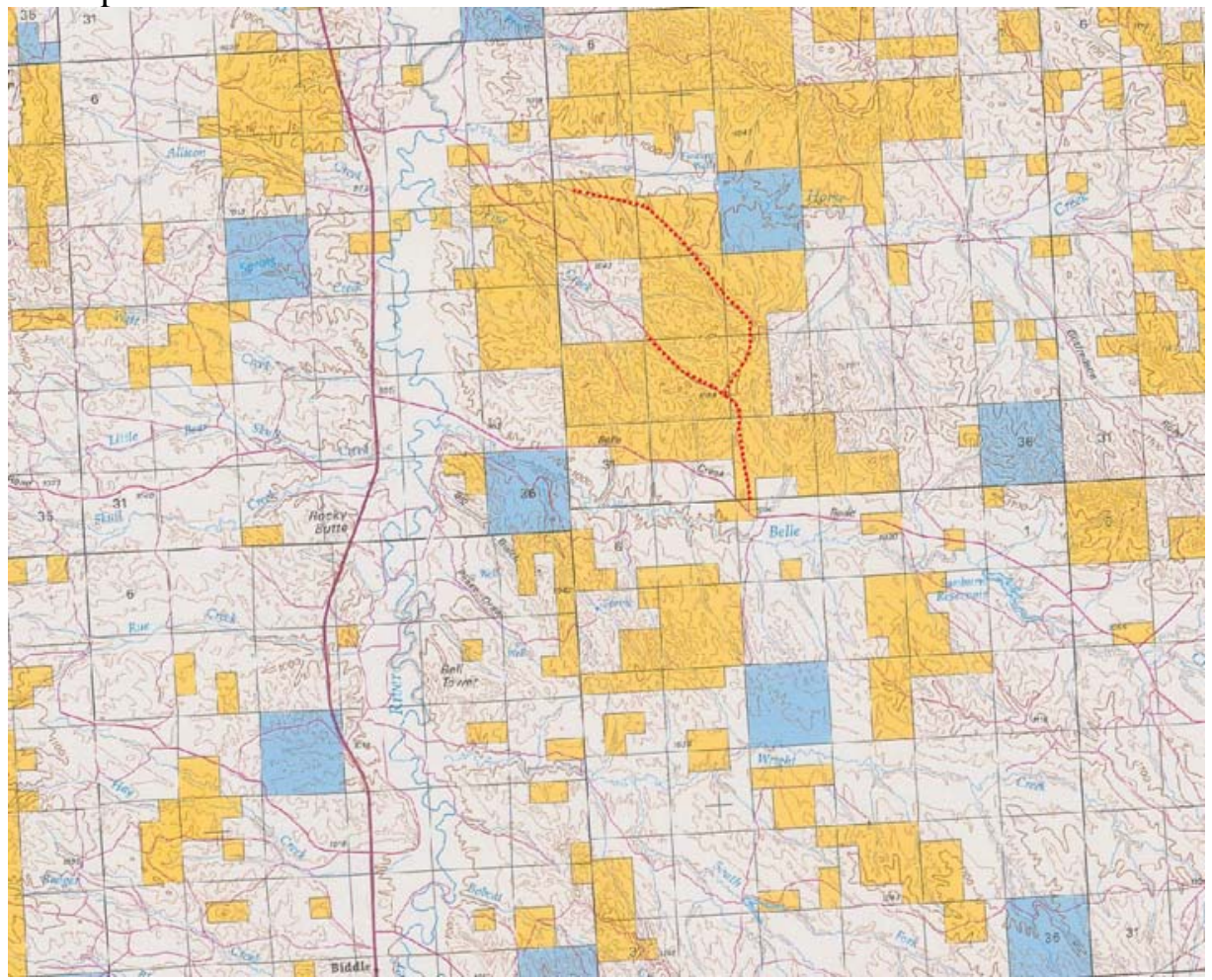


Map 13. Moorhead-Buffalo Creek-Spear Hills.

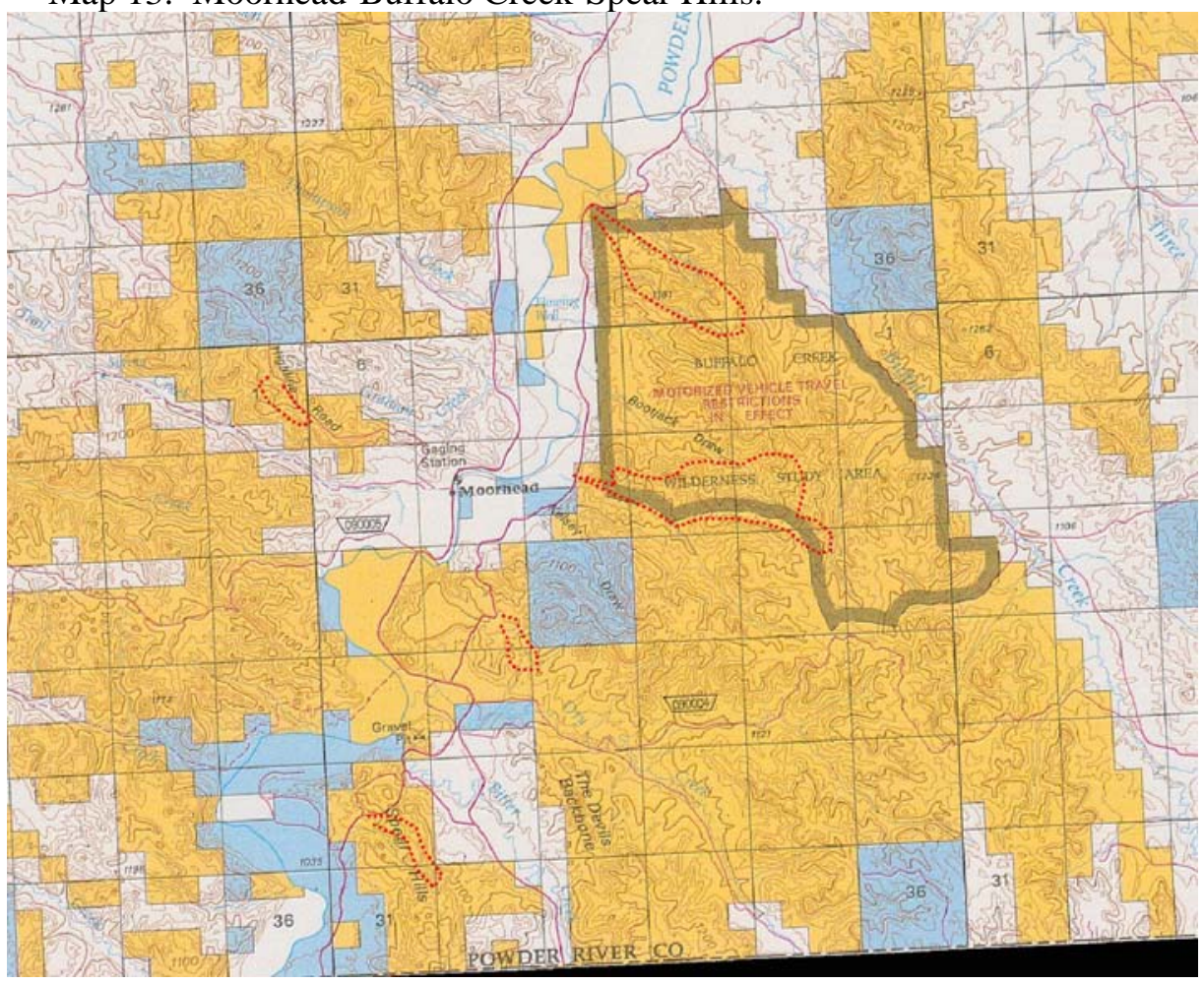

Map 14. Prong Creek.

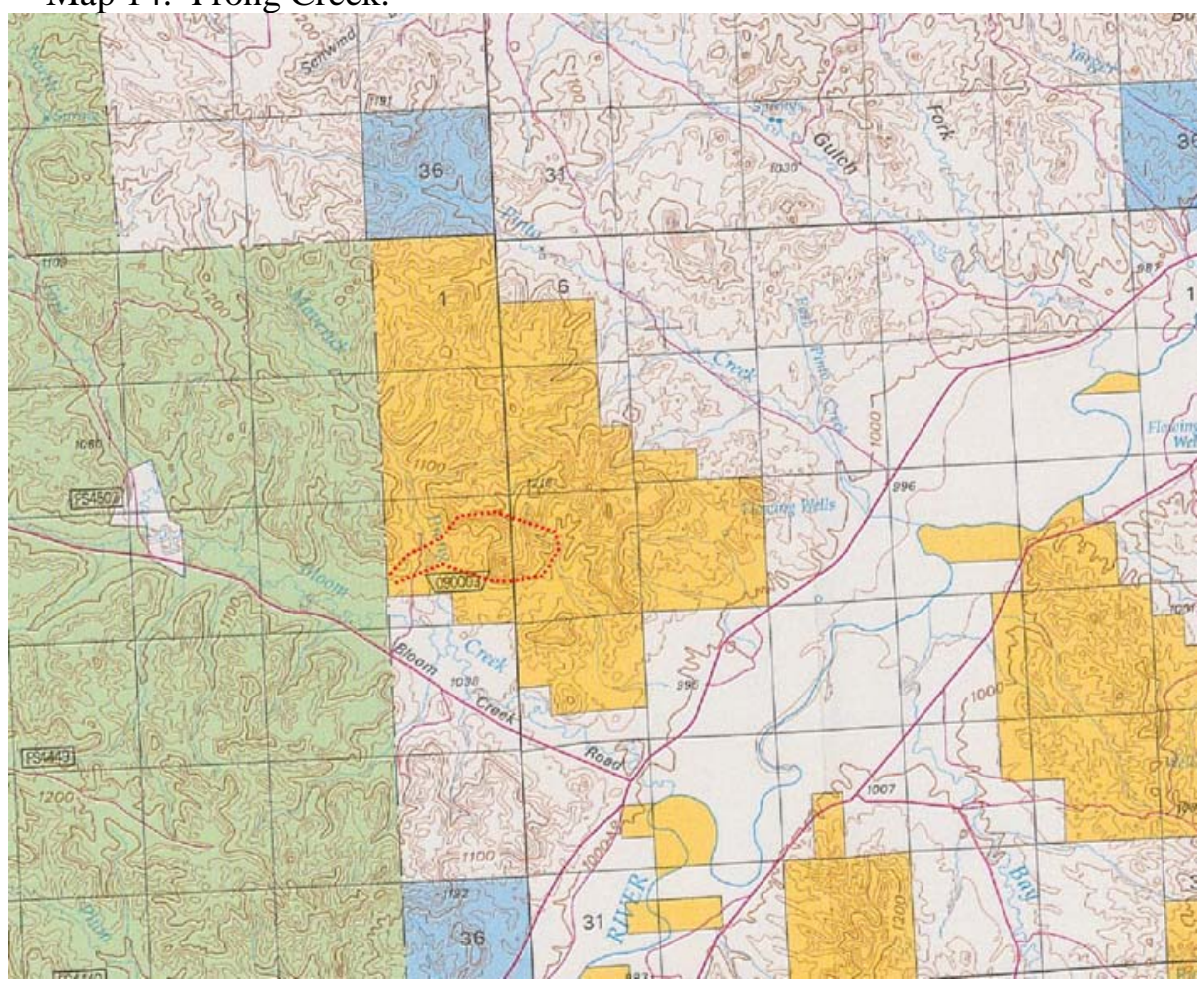

Appendix B - 8 
Map 15. Boxelder Creek-Bales Creek-Bear Creek.

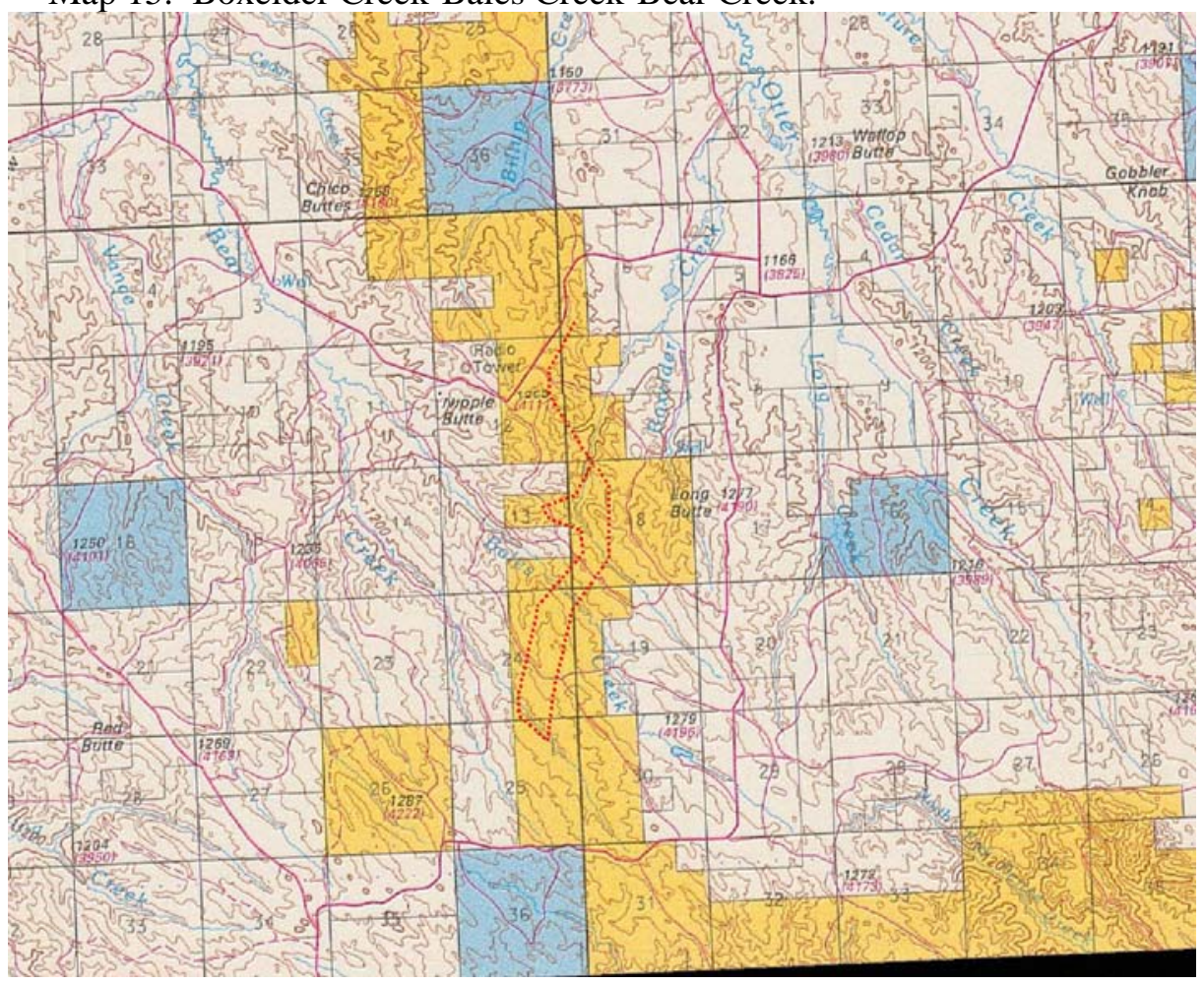

\section{Prairie County}

Map 16. Big Sheep Mountains (Surveyed BLM lands outlined in red).

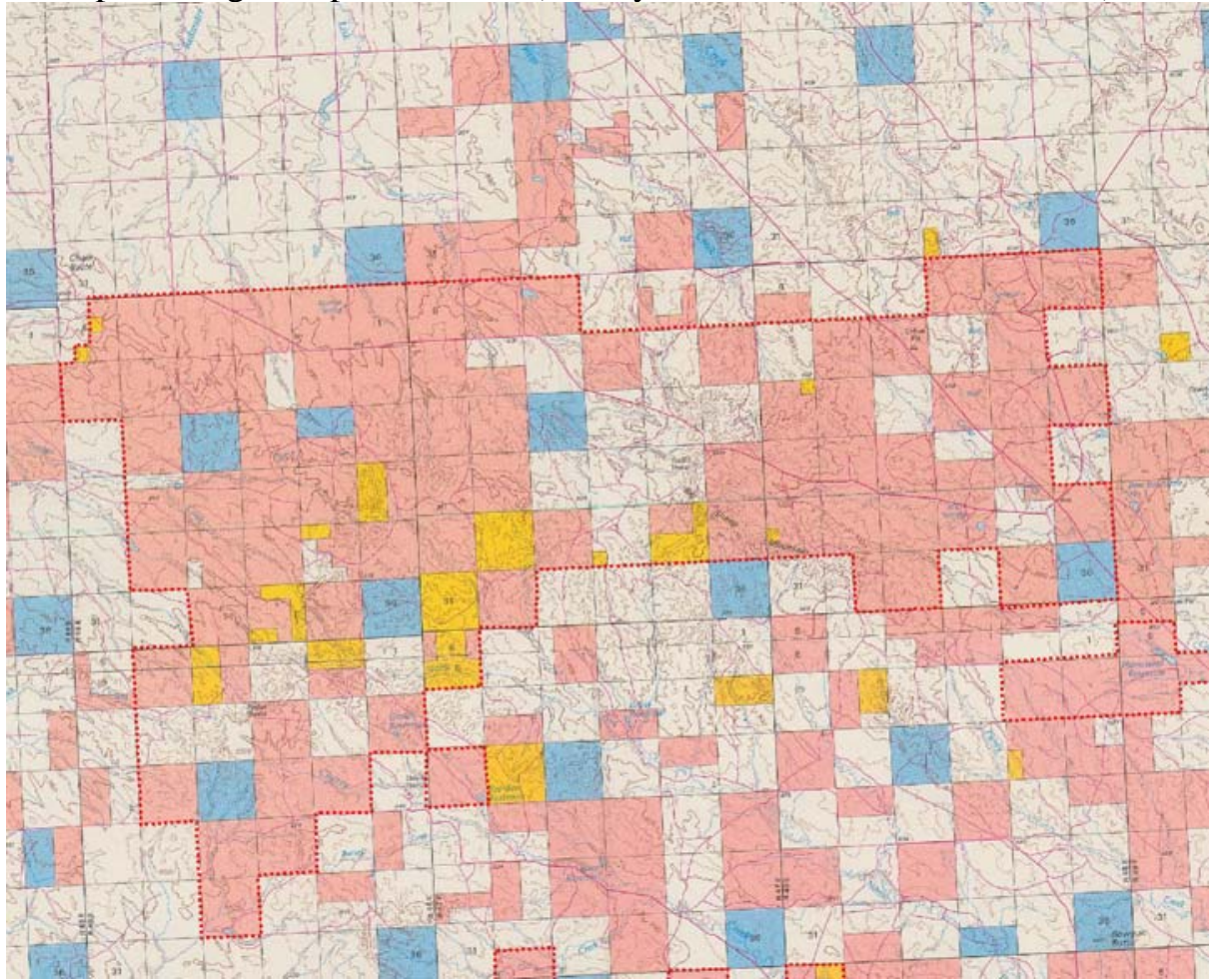


Map 17. Little Sheep Mountains (Surveyed BLM lands outlined in red).

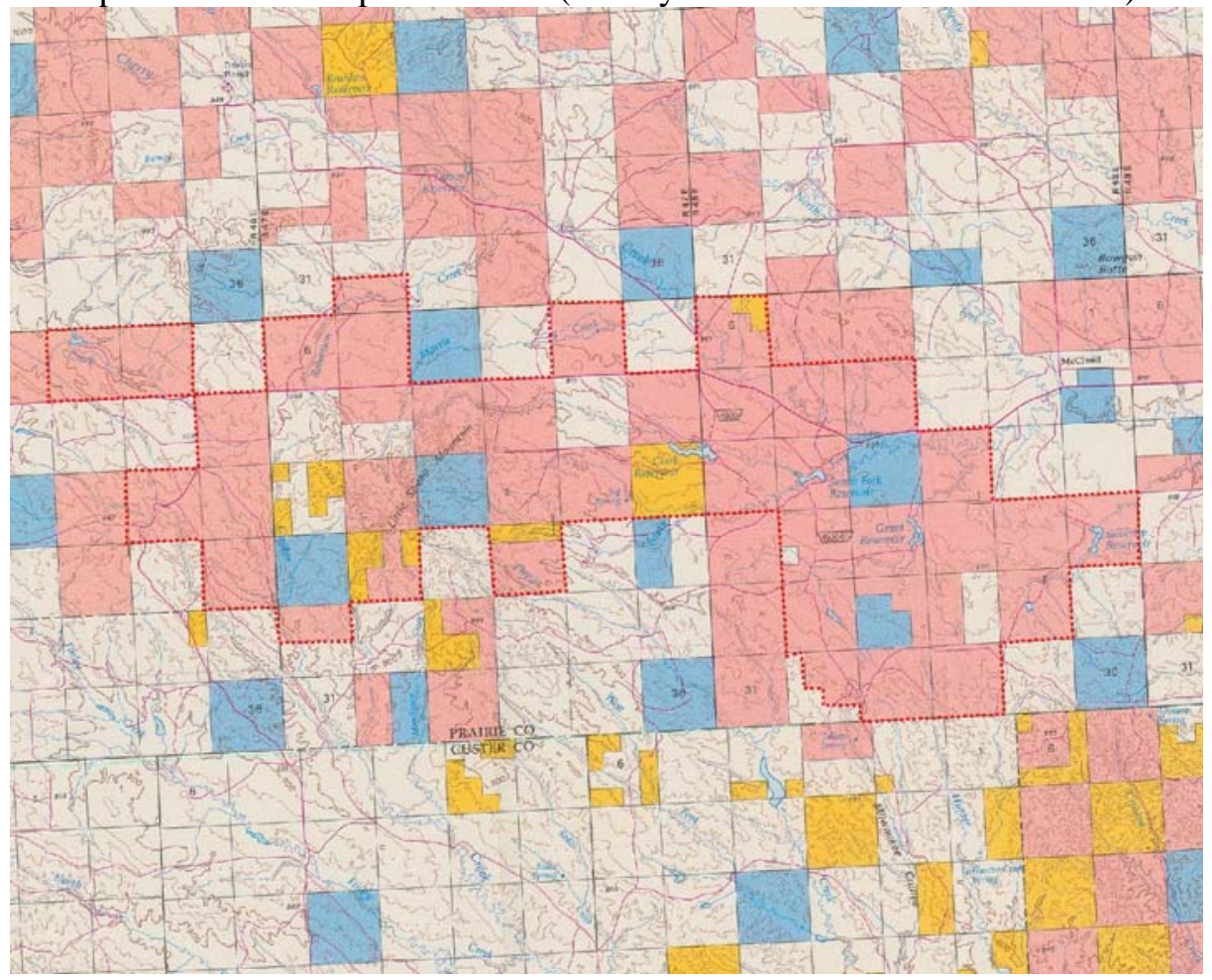

Map 18. Homestead and Innes Reservoirs (Surveyed BLM lands outlined in red).

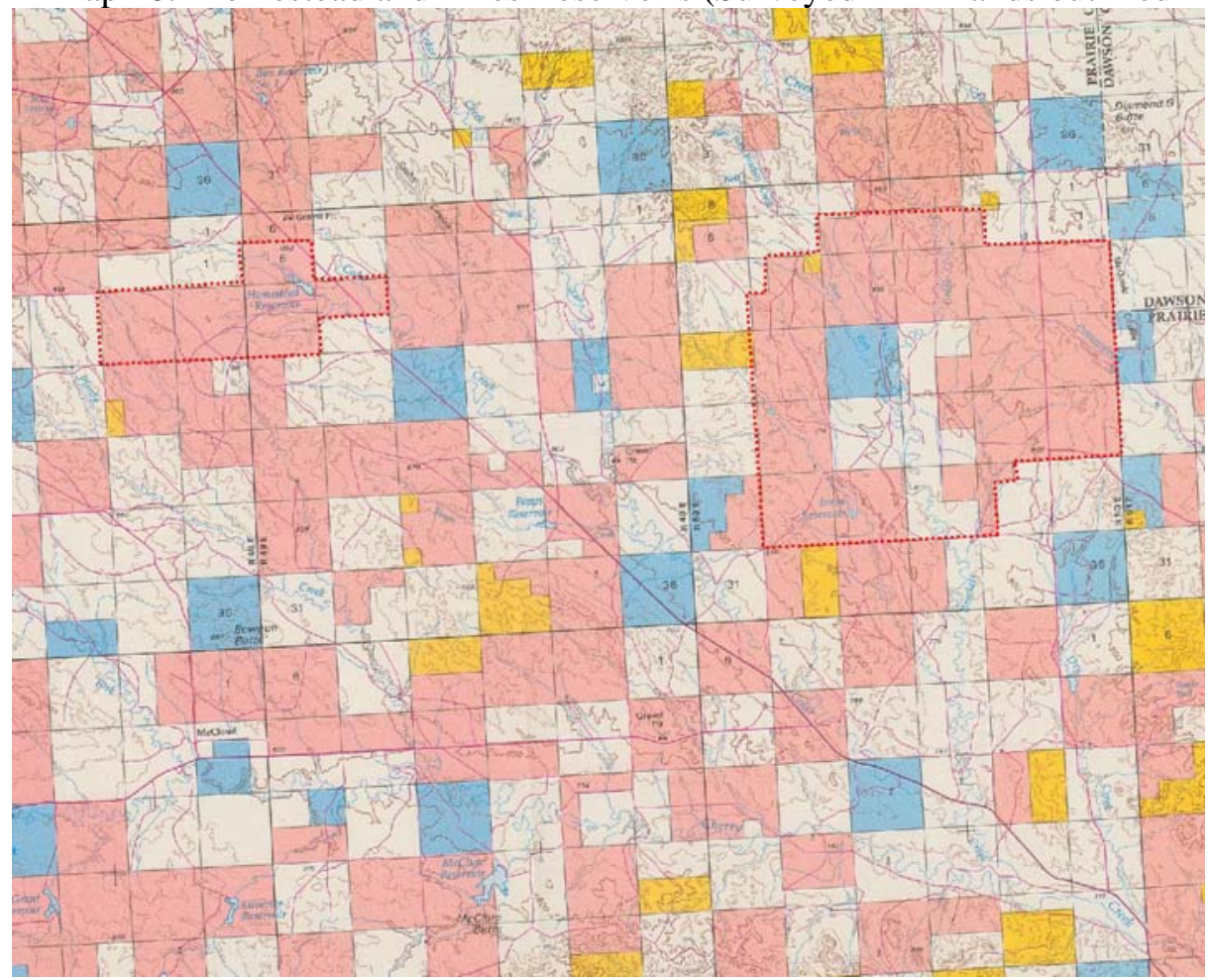

*Lands shaded in pink are Bankhead-Jones Lands administered by the BLM 


\section{APPENDIX C. SPECIES ACCOUNT FOR CIRSIUM PULCHERRIMUM}



Cirsium pulcherrimum (Asteraceae)

\title{
Wyoming Thistle
}

\author{
BLM Status: None \\ Heritage Ranking: G5/S1
}

RANK JUSTIFICATION: In Montana, known conclusively from one area of Powder River County where a small number of scattered individuals where observed in 2006. Also, reported for Dawson and Garfield Counties by Flora of the Great Plains (GPFA 1986).

IDENTIFICATION: Taprooted perennial with 1-few erect stems that are arachnoid-tomentose or sometimes glabrate. Flowers are pink to purple, $18-25 \mathrm{~mm}$ long. The 1 to several heads are borne singly or in 2-3-headed clusters at the tips of the main stem and branches in a typically open inflorescence, heads may also be present in distal axils. Leaf blades are linear to oblong, oblanceolate, or elliptic, 5-25 × 0.6-7 cm, unlobed and merely spinulose or spiny-dentate to regularly pinnatifid, typically with 5-8 pairs of lobes that are well separated, and usually with broad, U-shaped sinuses. Spines are slender and 2-7 mm long. Lower leaf surfaces are usually

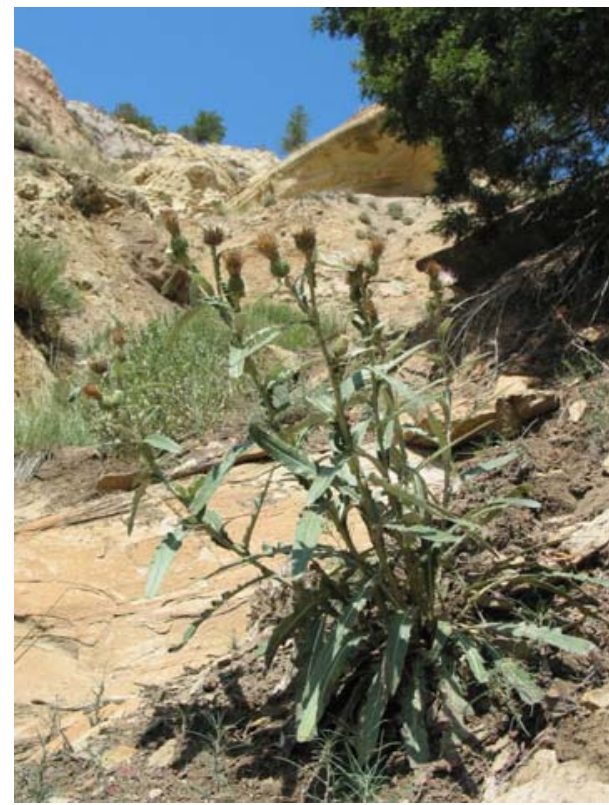

Cirisum pulcherrimum in the Buffalo Creek WSA densely arachnoid-tomentose, while upper surfaces are typically green, glabrous or less commonly thinly to densely gray-tomentose; basal leaves are often present at flowering. Cauline leaves well distributed along stem, gradually reduced upwards, lower leaves usually winged-petiolate, while mid and upper leaves typically are sessile, leaves decurrent along stem for 1.5-3.5 $\mathrm{cm}$. Involucres are ovoid to campanulate, $1.8-2.7 \times 1-2 \mathrm{~cm}$, thinly arachnoid-tomentose or glabrate. Bracts are in 6-7 overlapping series, green or with a dark subapical patch or appendage, linear to linearlanceolate, margins entire, abaxial faces with narrow glutinous ridge; outer and middle bases appressed, apical appendages spreading to stiffly ascending, linear-lanceolate to acicular, entire, spines spreading or

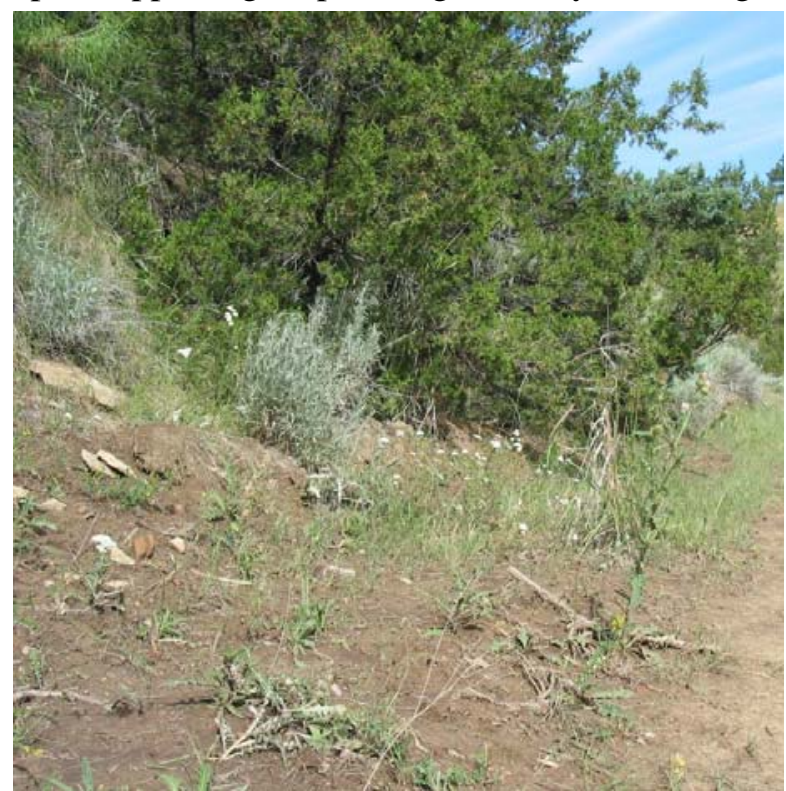

Cirsium pulcherrimum habitat ascending, stout, 2-7 mm, often flattened; apices of inner bracts erect or sometimes flexuous, narrow, flat. Pappus is 14-16 mm long. (adapted from treatment in Flora of North America vol 19).

Flowering occurs in June to July.

Similar species include Cirsium canescens and $C$. flodmanii both of which occur in eastern Montana. The former can usually be distinguished by having the upper leaf surfaces being slightly tomentose and by the leaf lobes being over 3.5 times as long as wide. The latter species usually has stem leaves that only clasp the stem or are short-decurrent compared to the typically, long-decurrent leaves (middle leaves with wings usually $>15 \mathrm{~mm}$ long) of $C$. pulcherrimum. A technical manual should be consulted for positive identification. 
HABITAT: Sparsely-vegetated soils of washes and steep, eroded gullies in dissected or badlands topography. Associated species include Juniperus scopulorum, Chrysothamnus nauseosus, Artemisia ludoviciana, Atriplex confertifolia and Elymus trachycaulis. In other areas, this species is listed as typically growing in rocky or stony soils. However, in our area the species has also been noted from finetextured soils.

GLOBAL RANGE: Eastern Montana, south to Wyoming, n Colorado, ne Utah, nw Nebraska and west to se Idaho.

ECOLOGY AND MANAGEMENT:

The effects, if any of the introduced Rhinocyllus weavil on this species are unknown. Additional information on this species' ecology and management in Montana are lacking at this time.

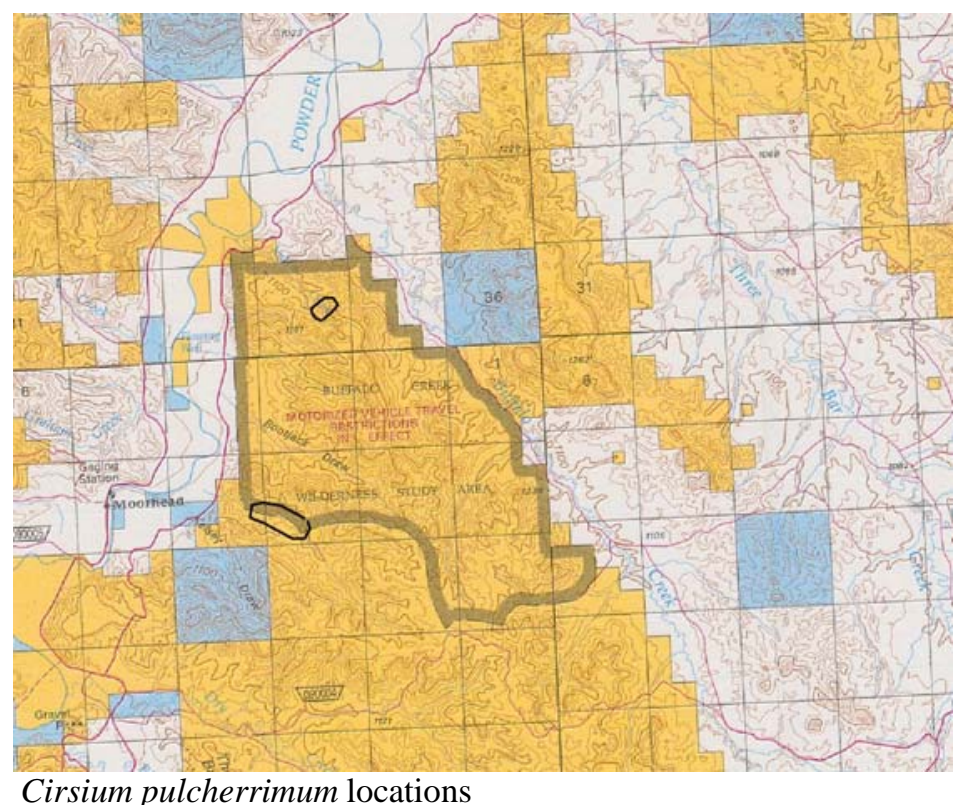

